\title{
Trash or Treasure? \\ Te Papa and the collecting of everyday material culture
}

\author{
by \\ Amy Hackett
}

A dissertation submitted to Victoria University of Wellington in partial fulfilment of the requirements for the degree of Master of Museum and Heritage Studies 


\section{Table of Contents}

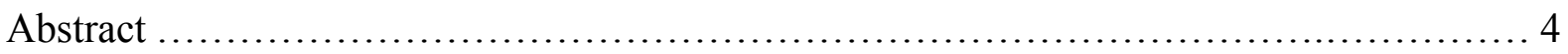

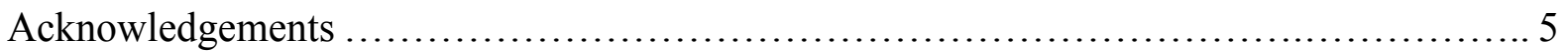

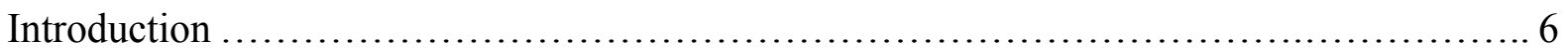

Literature review .................................................................. 7

Research design ...................................................... 16

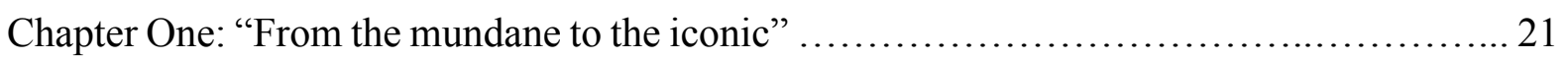

Chapter Two: Everyday material culture at Te Papa .................................... 29

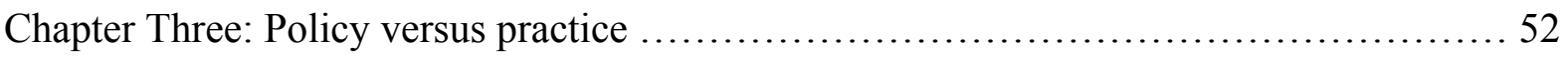

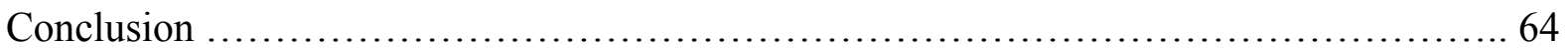

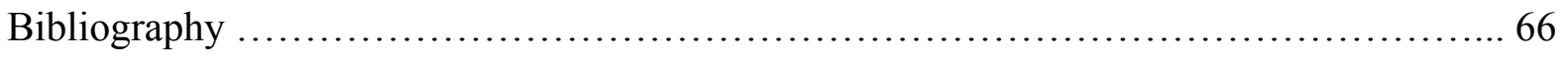

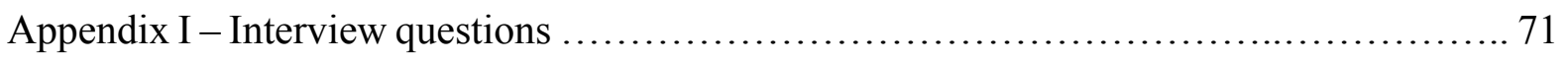




\begin{abstract}
The everyday, ordinary, and mundane are categories of material culture that challenge traditional museum collecting. Collection planning is an absolute necessity for museums if they are to avoid becoming unmanageable time capsules. With cuts to resources and space now at a premium, it is important that museums clarify their purpose and begin to collect more strategically. This dissertation asks: if collecting everyday material culture is now an accepted part of curatorial practice today, then how does Te Papa approach this fraught task? How does the museum define the everyday, how much of it already exists in the museum's collections, and what tools and strategies does it deploy to ensure that these objects are collected and appreciated as part of the nation's history and heritage?
\end{abstract}

Using a multi-method approach comprising document analysis, interviews and observation, this dissertation provides insight into how Te Papa collects everyday material culture. It provides an in-depth view of the national museum's current collecting processes, all the way from how it collects on paper, to how it collects in reality. The research addresses gaps in literature on institutional collecting, particularly in a national museum setting. Building on work by James B Gardner and Simon Knell, and by observing and interviewing curators, this study is able to respond to calls for research that approaches collecting from an internal 'onthe-ground' viewpoint.

Trash or Treasure? reveals that at Te Papa, although everyday material culture is being collected and displayed, it exists at a crossroads of traditional and contemporary conceptions of collecting. Policy enables collecting of these everyday objects provided acquisition proposals demonstrate national significance. However, curators are less concerned with this aspect of an object. This discrepancy occurs because of the challenging nature of everyday material culture, namely its mutability; it can be all things to many people. The findings suggest that policy does not always trump practice unless strict approval processes are put in place. In order to build a strong collection, this dissertation argues that museums need to find a balance between careful planning while also allowing space for unexpected collecting opportunities. 


\section{Acknowledgements}

First and foremost, thank you to my supervisors, Dr Conal McCarthy and Kirstie Ross. Your encouragement and guidance was a constant support to me throughout the year. I am incredibly grateful.

To the curators at Te Papa, thank you for giving me your time and allowing me to interview you and attend your meetings. This research would not have been possible without your insights, thoughts and opinions.

To my place of work, Alexander Turnbull Library, thank you for all the study leave and support. Studying and working was challenging and you made it easier. To my fellow library assistants, thank you for all the cheese scones and for, more often than not, bearing the brunt of my stress.

Finally, thank you to my family and friends. I am so very lucky to have you all. 


\section{Introduction}

The everyday, the ordinary, the mundane and the mass-produced are categories of material culture that challenge traditional museum collecting for a number of reasons, especially because of its sheer profusion or ubiquity. ${ }^{1}$ Graeme Were boldly states that,

The size of many museum collections today now means that many objects will never be displayed. Instead collections ... act as a future resource, a database never intended for exhibition. ${ }^{2}$

This extract from the introduction to Were's Extreme Collecting sets out a problematic reality for museums today. With limited time, resources and space, museums now need to think more carefully about what objects they choose to collect in order to avoid becoming "unmanageable time capsules." "3 This dissertation explores how one museum has collected everyday material culture, while simultaneously trying to manage the threat of unmanageable time capsules developing in its storerooms.

I first became interested in how heritage institutions collect everyday objects through my work at Alexander Turnbull Library. Between 1988 and 1989 Turnbull Library staff, under the supervision of Helen Loftus and Walter Cook, collected 100 pieces of commercial packaging. A Steinlager can, a Beehive matchbox, and a package for Johnson \& Johnson KY Jelly, which many would view as rubbish, now have a permanent home in a national heritage institution. It sparked many questions for me, namely around why these objects were deemed important to collect and whether they truly fit into Turnbull's collection policy. Later that same year, I came across an article by Kirstie Ross about the development of the exhibition The Scots in New Zealand at the Museum of New Zealand Te Papa Tongarewa (Te Papa). ${ }^{4}$ Ross referenced Robert Leonard's criticism of social history museums failing to

\footnotetext{
${ }^{1}$ Susan Pearce, "Knowing the new." In Extreme Collecting: Challenging practices for 21st century museums, edited by Graeme Were and J.C.H. King, (New York: Berghahn Books, 2012), 93.

${ }^{2}$ Graeme Were, "Extreme Collecting: Dealing with difficult objects," In Extreme Collecting: Challenging practices for 21 st century museums, edited by Graeme Were and J.C.H. King, (New York: Berghahn Books, 2012), 10 .

${ }^{3}$ Ibid.

${ }^{4}$ Kirstie Ross, "Materialising Social History in Museums," Te Ara Journal of Museums Aotearoa 32, no. 1-2 (2007), accessed March 12, 2016, http://www.museumsaotearoa.org.nz/sites/default/files/te ara/3212krmalow.pdf
} 
successfully display social history. This caused Ross to state, 'How can history curators mesh storytelling and social history in museums with collections that bear the mark of longstanding organising principles such as taxonomies, the 'hall of fame', 'icons', social progress, excellence, innovation, and connoisseurship? ${ }^{5}$ While Ross's question above relates to issues surrounding the display of objects, it also directly addresses the issue of what kind of objects museums should be collecting. After all, how can you display that which has not been collected?

This dissertation asks: if collecting everyday material culture is now an accepted part of curatorial practice today, then how does Te Papa approach this fraught task? How does the museum define the everyday, how much of it already exists in the museum's collections, and what tools and strategies does it deploy to ensure that these objects are collected and appreciated as part of the nation's history and heritage? In addressing these questions, this dissertation makes several broader points that can be drawn from this close examination of policy and practice. It focuses on how everyday material culture has been, and is currently being, collected at Te Papa. The aim of this research is to provide some indicative conclusions as to how objects of everyday material culture fit in to a collection plan, using an in depth analysis of Te Papa's collecting practices.

\section{Literature review}

This review outlines the literature that has shaped this research. It brings together writing on material culture, museums, and collecting practices with a focus on museums in New Zealand. It begins with material culture studies; an overview of institutional collecting then follows, highlighting the gap in the literature on museums' current collecting activities, particularly from an internal perspective. It concludes with a survey of museum practice in New Zealand, including Te Papa, focussing on research that explores contemporary collecting practices.

\section{Material Culture}

Material culture, and how to use it as a research tool, has been widely written about by scholars in a number of disciplines. ${ }^{6}$ Ian Woodward defines material culture as something

\footnotetext{
${ }^{5}$ Ross, "Materialising Social History in Museums," 2.

${ }^{6}$ Karen Harvey (ed.), History and Material Culture: A student's guide to approaching alternative sources, (Oxon: Routledge, 2009); Giorgio Reillo, "Things that shape history: material culture and historical narratives,"
} 
that is "portable and perceptible by touch and therefore has a physical, material existence that is one component of human cultural practice." 7 Thomas J. Schlereth states that in scholarship, the term material culture is often used interchangeably with other terms such as 'artefacts,' 'objects,' and 'things. ${ }^{8}$ Schlereth believes, however, that terms such as these fail to suggest implied human agency as they can instead be used to refer to anything that exists in the environment, both naturally and man-made. ${ }^{9}$ The term material culture differs from this in that it implies a direct link between object and human. With this in mind, Schlereth provides the following working definition for material culture: "material culture is that segment of humankind's biosocial environment that has been purposely shaped by people according to culturally dictated plans." ${ }^{\prime 10}$ Material culture is therefore the result of human agency upon the material world, ranging from objects humans create and use, to their physical impact on the world.

Within a museum context the phrase 'material culture' is closely associated with anthropology. Having lately been appropriated by many history curators, the term has become even more layered, and material culture has opened itself up to even further definitions. In his Museum Studies thesis 'City revealed', Daniel Smith provides a narrower definition of material culture, perhaps better suited to research concerning museum collections than the broad one provided by Schlereth. ${ }^{11}$ Using Susan Pearce's work around material culture and museums, Smith defines material culture as: "the material world we usually refer to when we talk of accumulating; that is the area of discrete materials, for which 'object' or 'thing' or 'piece' is our usual word, meaning an item which can, perhaps with some difficulty, be lifted up from its immediate surroundings and moved somewhere else." ${ }^{\text {"12 }}$ This definition has helped my research because of the museum studies context in which it was developed.

\footnotetext{
In History and Material Culture: A student's guide to approaching alternative sources, edited by Karen Harvey, (Oxon: Routledge, 2009); Thomas J. Schlereth, Material Culture: A research guide, (Lawrence: University Press of Kansas, 1985).

${ }^{7}$ Ian Woodward, Understanding Material Culture, (London: SAGE Publications Ltd, 2009), 14.

${ }^{8}$ Schlereth, Material Culture, 2.

${ }^{9}$ Woodward, Understanding Material Culture, 3.

${ }^{10}$ Woodward, Understanding Material Culture, 5.

${ }^{11}$ Daniel Smith, “City revealed: The process and politics of exhibition development," Master's Thesis, Massey University, 2003.

12 Smith, "City revealed," 18.
} 
Material culture studies can be approached from a number of different disciplines, including anthropology, archaeology, sociology and history. As a result, it can also carry with it a number of different meanings and uses. ${ }^{13}$ Woodward defines material culture studies as the study of the relationship between people and objects - of what uses people put objects to, and of what objects do for, and to, people. ${ }^{14}$ He often stresses the power objects can have over us. ${ }^{15}$ Even the most commonplace object, he states, has the ability to, 'symbolise the deepest human anxieties and aspirations. ${ }^{16}$ He suggests that, by studying objects and the relationship people have with them, we are able to better understand modern consumption, identity and culture. $^{17}$

Daniel Miller, Professor of Anthropology at University College London, provides a strong argument for the importance of mass-produced consumer goods. He argues that these objects should not be dismissed as being irrelevant, but instead viewed as crucial elements in understanding culture. ${ }^{18}$ Mass-produced objects are integral to the 'process of objectification through which we establish our identities, affiliations and practices in everyday life. ${ }^{19}$ Identity-building is a strong theme throughout material culture studies and both Miller and Woodward argue that material culture is crucial to identity. ${ }^{20}$ The material things we surround ourselves with help to create our personal and social identities. ${ }^{21}$

While material culture studies plays a role in disciplines concerned with cultural identity, this research investigates it in relation to its role in building social histories. That it has this role is confirmed by its almost exclusive use at Te Papa by the history team rather than the Mātauranga Māori, Pacific Cultures or art teams. I would argue that material culture, which materialises the past, provides unique historical insight, and material culture studies is an effective way to reflect this form of historical practice. There is a strong argument to be made about the opportunities for historical interpretation that material culture provides. Internationally, Georgio Reillo has written extensively on the topic, and there are several

\footnotetext{
${ }^{13}$ Harvey, History and Material Culture.

${ }^{14}$ Woodward, Understanding Material Culture, 14.

${ }^{15}$ Woodward, Understanding Material Culture, vi.

${ }^{16}$ Ibid.

${ }^{17}$ Woodward, Understanding Material Culture, vii.

${ }^{18}$ Daniel Miller, Material Culture and Mass Consumption, (Oxford: Basil Blackwell, 1987), 215.

${ }^{19}$ Miller, Material Culture and Mass Consumption, 215; Woodward, Understanding Material Culture, 55.

${ }^{20}$ Woodward, Understanding Material Culture, 137.

${ }^{21}$ Woodward, Understanding Material Culture, 133-134.
} 
New Zealand examples available that effectively demonstrate how material culture can be used to build histories. ${ }^{22}$

Bronwyn Labrum's recent publication Real Modern: Everyday New Zealand in the 1950s and 1960s is a strong example of what she calls 'material history'. In Real Modern, Labrum demonstrates how everyday objects can be of importance to her readers, even after they no longer have a practical use. ${ }^{23}$ Linking back to the arguments of Woodward and Miller, Labrum writes of the power of objects, to remind us of the meanings that people give to things, and shows how ultimately it is impossible to separate people, things and society. ${ }^{24}$ The importance of objects in narrating histories is also pointed out by Conal McCarthy and Jonathan Mane-Wheoki. They suggest that studying objects enriches our understanding of the past, and, because they are physical, they are able to bring the past into the present. ${ }^{25}$

While everyday material culture can be important for writing histories, it plays a role within museums. Recently museum studies have tended to focus on the making of meaning, however Sandra H. Dudley believes it is now necessary to see material focussed, material culture studies back at the centre of museum practice. ${ }^{26}$ She wants to see the object back at the heart of the museum, 'this time as a material focus of experience and opportunity, a subtle and nuanced, constructed, shifting thing, but also physical, ever present, beating pulse of potential, quickening the institution and all that it is and could be. ${ }^{27}$ Dudley argues that before a museum visitor formulates any ideas towards an object, they will already have an emotional and physical response. It is in this engagement between subject and object, she believes, that 'sensory responses, emotions and ideas are generated. ${ }^{, 28}$ It is only in this engagement that subjects and objects come fully into being at all. ${ }^{29}$ As McCarthy and Mane-

\footnotetext{
${ }^{22}$ Reillo, "Things that shape history"; Kate Hunter and Kirstie Ross, Holding on to Home: New Zealand stories and objects of the First World War, (Wellington: Te Papa Press, 2014).

${ }^{23}$ Bronwyn Labrum, "Material Histories in Australia and New Zealand: Interweaving distinct material and social domains," History Compass 8, no. 8 (2010): 805-816 and Bronwyn Labrum, Real Modern: Everyday New Zealand in the 1950s and 1960s, (Wellington: Te Papa Press, 2015).

${ }^{24}$ Labrum, Real Modern, 15-16.

${ }^{25}$ Conal McCarthy and Jonathan Mane-Wheoki, "Afterword: the Wharenui Mataatua, and some thoughts about things," In The Lives of Colonial Objects, ed. Annabel Cooper, Lachy Paterson and Angela Wanhalla, (Dunedin: Otago University Press, 2015), 314-316.

${ }^{26}$ Sandra H Dudley, "Encountering a Chinese Horse: engaging with the thingness of things," In Museum Objects: Experiences the Properties of Things, ed. Sandra H. Dudley, (Oxon: Routledge, 2012), 5.

${ }^{27}$ Ibid.

${ }^{28}$ Dudley, "Encountering a Chinese Horse," 8.

${ }^{29}$ Ibid.
} 
Wheoki put it, this object-centred approach 'allows for an understanding of things as well as words. $^{30}$

\section{Collecting}

As well as material culture studies, the literature surrounding institutional collecting provided important context for my research. Sharon McDonald argues that the perception or belief that collecting is a basic instinct or fundamental human activity is problematic for museums. This is because it naturalises museum collecting, 'casting it as an inevitable expression of the collecting urge rather than seeking to understand its various manifestations and flourishing in specific historical and cultural contexts. ${ }^{31}$ Museum collecting, McDonald states, should be seen as a practice in which the intention is to create a coherent collection, which will in turn, form some kind of meaningful 'whole.' 32 This 'whole', will however, never be 'complete' and McDonald acknowledges the problems museums face when it comes to selecting meaningful objects. Collecting undertaken by museum curators needs to be carried out carefully, 'sifting the meaningful from the dross, on one hand, and seeking to be properly comprehensive, on the other. ${ }^{33}$

In the twentieth century, as new ideas surrounding the use material culture as a means of reinforcing identities began to emerge, museum collecting and exhibitions moved from the rare and exotic and toward the everyday. ${ }^{34}$ More recently, social history collecting began to gain steam in the 1970s and 1980s, with the nineties seeing an increase in museums collecting the everyday and mass-produced. McDonald links this to the changing museumsociety relationship, where museums were evolving from elitist institutions into places responsible for representing diverse societies. ${ }^{35}$ This change, the result of museums shifting from 'temple' to 'forum', as argued by Steven Conn, is also touched on by Susan Pearce, who argues that contemporary collecting has placed an emphasis on mass-produced material which challenges the bounds of acceptable practice. ${ }^{36}$

\footnotetext{
${ }^{30}$ McCarthy and Mane-Wheoki, "Afterword," 318.

${ }^{31}$ Sharon McDonald, "Collecting Practices," in A Companion to Museum Studies, ed. Sharon McDonald, (Oxford: Blackwell Publishing Ltd, 2006), 81.

${ }^{32}$ McDonald, "Collecting Practices," 82.

${ }^{33}$ McDonald, "Collecting Practices," 87.

${ }^{34}$ McDonald, "Collecting Practices," 88.

${ }^{35}$ McDonald, "Collecting Practices," 92.

${ }^{36}$ Steven Conn, Do Museums Still Need Objects? (Philadelphia: University of Pennsylvania Press, 2010);

Pearce, "Knowing the new," 93-101.
} 
Literature on institutional collecting, collecting policies, how they have changed throughout time, and in particular, how they may need to change in the future touches on the issues faced by Te Papa. ${ }^{37}$ Simon Knell for example argues that "collecting policies need to be replaced by strategies which adopt a more long-term, holistic, inclusive, integrated, cooperative, sustainable, rational and thoughtful view of the purpose of institutional collecting. ${ }^{\text {"38 }}$ In order to do this, Knell believes that museums are in need of a deeper understanding of material culture, how it works in society and how it can be made to work in a museum. Material culture, according to Knell, tells little without other means of collecting such as oral history and accounts. ${ }^{39}$ He argues that the social historian should therefore be collecting other things alongside objects, 'simple object collecting for the purposes of making social history is unsupportable. ${ }^{40}$

Linda Young's development of two ideas on the nature and practice of collecting provide guidance for how museums approach, or should approach, collecting. Working with the idea that museum collecting is now driven by exhibition needs, she proposed in 1994 that the art of connoisseurship be claimed as the "unique and special skill of curators" and removed from the elitist connection it has held since the nineteenth century. ${ }^{41}$ Secondly, she proposed that museums need to make their collecting decisions more systematic and explicit. ${ }^{42}$ Ten years later, she put forward these proposals once more, with the hope that steps towards them would, 'revive the honourable traditions of the curator, the specialist collector and the connoisseur. ${ }^{43}$ Some recent criticism note the absence or misinterpretation of social groups in the museum record of material culture. ${ }^{44}$ However, Young concludes this article by suggesting that museum collecting needs to become much more transparent and more accountable. ${ }^{45}$ While transparency and accountability might not directly relate to my research, it is useful context, especially if museums need to justify acquisitions. However, it

\footnotetext{
${ }^{37}$ Simon J. Knell (ed). Museums in the Material World. (Oxon: Routledge, 2007); Pearce, "Knowing the new."

${ }^{38}$ Knell, Museums in the Material World, 15.

${ }^{39}$ Knell, Museums in the Material World, 30.

40 Ibid.

${ }^{41}$ Linda Young, "Significance, connoisseurship and facilitation: New techniques for assessing acquisitions," Museum Management and Curatorship 13, no. 2 (1994).

${ }^{42}$ Young, "Significance, connoisseurship and facilitation," 191.

${ }^{43}$ Linda Young, "Collecting: reclaiming the art, systematising the technique," In Museums and the Future of Collecting (Second Edition), ed Simon J Knell (Aldershot: Ashgate Publishing Limited, 2004), 185.

${ }^{44}$ Young, "Collecting," 194-195.

45 Ibid.
} 
may be difficult for museums to justify the collecting of everyday items, compared to pieces of obvious significance.

Nick Merriman believes there is a lack of debate around how collections can be developed for the future, and how museums can reinstate active collecting as a part of their fundamental activities. ${ }^{46}$ Referring directly to museums in the UK, Merriman believes that almost no museum sees collecting as a significant part of its work, a direct result of them moving from an inward focus on collecting to an outward focus on audiences from the 1990s onward. ${ }^{47}$ The changes in museums over the last century, have clearly impacted the discipline of collecting. Although his focus is on regional, not national, museums, he makes important points about collecting that can be applied to national museums. Collecting in the UK has been shaped by standard collecting policies, has been reactive instead of active, and been related too closely to individual curators' own disciplinary priorities, rather than looking at the wider work of the museum. ${ }^{48}$ The future of collecting, Merriman states, 'is to accept that it is interpretive, then to collect scientifically within this framework ... this scientific collecting should be selective rather than quasi-comprehensive, and thematic rather than disciplinary. ${ }^{49}$

Although Merriman states that disposal is only one element in an overall approach to the development of museum collections, it is a theme often found throughout the literature that addresses the future of museum collecting. ${ }^{50}$ If loose collecting policies in the past have enabled objects to flow into museums, then permissive deaccessioning strategies at the other end are an obvious solution. Knell argues that current practice means that museums collect and keep objects to be kept in perpetuity. ${ }^{51}$ However, he calls for the 'single dynamic act of balance', allowing objects to flow in and out of museum collections. ${ }^{52}$ Knell states that this approach will ensure museums do not become "places for redundant things." ${ }^{, 53}$ While

\footnotetext{
${ }^{46}$ Nick Merriman, "The Future of Collecting in "Disciplinary” Museums: Interpretive, Thematic, Relational,” In The International Handbooks of Museum Studies: Museum Practice, ed. Conal McCarthy, (John Wiley \& Sons, Ltd: 2015), 249.

${ }^{47}$ Merriman, "The Future of Collecting," 250.

${ }^{48}$ Merriman, "The Future of Collecting." 254.

${ }^{49}$ Merriman, "The Future of Collecting," 253-254.

${ }^{50}$ Merriman, "The Future of Collecting," 249.

${ }^{51}$ Knell, Museums in the Material World, 18.

${ }^{52}$ Knell, Museums in the Material World, 17.

${ }^{53}$ Knell, Museums in the Material World, 20.
} 
deaccessioning is a recurring theme in studies about how museums should collect, it is outside my own study, with examples of deaccessioning in practice already cited. ${ }^{54}$

James B. Gardner identifies the gaps that exist within contemporary collecting. Unlike the others cited, he writes about his concern around the limited nature of museum collecting. ${ }^{55}$ Labrum also highlights the significance of gaps in museum collections in her introduction to Looking Flash. ${ }^{56}$ While much of the material evidence used in the book relied on the initiative and foresight of museum curators, she notes the absence of some material in museums. ${ }^{57}$ These absences strengthen the argument that museums may have neglected the everyday objects, in favour of the special and exotic. ${ }^{58}$ The importance of collection planning is emphasised by Gardner who states that literature on museum collections tends to focus on intellectual issues at a higher level. He identifies a gap in practical on-the-ground research into the problems of museums and collection responsibilities and resources. This focus on the operational, every day issues which surround museum collections provides important context and arguments for my research.

\section{Museum practice in New Zealand}

A lot has been written on museum practice in New Zealand, both by individual researchers and by the staff at the museums themselves. This all shows an element of self-reflexivity and awareness of how and why museums collect. In a broader New Zealand context, research into the collecting practices of Auckland Museum, Otago Settler's Museum, Wellington Museum, and Dunedin Public Art Gallery is readily available through dissertations, and articles and research completed by their own staff alike. ${ }^{59}$

\footnotetext{
${ }^{54}$ Rebecca Loud, "Never let me go? A case study of deaccessioning and disposal undertaken at Museum of Wellington City and Sea." Master's thesis, Victoria University of Wellington, 2013; Frances Speer, "Good use: a study of collection utilization at the Dunedin Public Art Gallery." Master's thesis, Victoria University of Wellington, 2006.

55 James B. Gardner, "From Idiosyncratic to Integrated: Strategic Planning for Collections." In The International Handbooks of Museum Studies: Museum Practice, edited by Conal McCarthy, (John Wiley \& Sons, Ltd: 2015).

${ }^{56}$ Bronwyn Labrum, "Dressing History Up: Introduction.” In Looking Flash: Clothing in Aotearoa New Zealand, edited by Bronwyn Labrum, Fiona McKergow and Stephanie Gibson, (Auckland: Auckland University Press, 2007), 1-11.

${ }^{57}$ Labrum, "Dressing History Up," 7.

${ }^{58}$ Labrum, "Dressing History Up," 8.

${ }^{59}$ Sean G. Brosnahan To Fame Undying: The Otago Settlers Association and its museum, 1898-1998, (Dunedin: The Association, 1998); Rosanne Livingstone, "The History and Development of Foreign Ethnology Collections in Museum of New Zealand Te Papa Tongarewa. Tuhinga 10 (1998): 1-29; Athol McCredie, "Collection photographs: The development of Te Papa's historical photography collection." Tuhinga 20 (2009): 41-66;
} 
In undertaking my research, it was important to acknowledge work which currently exists around Te Papa's own contemporary collecting, including work which has been written by Te Papa staff. ${ }^{60}$ There is also an increasing amount of research that has discussed collection practices at Te Papa. In her thesis, Chloe Searle examines how staff at Te Papa decide what to collect, and to what extent the views of the public are taken into account when making these decisions. ${ }^{61}$ Both Searle's and Matariki Williams' work provides important precedent for writing about the collecting decisions Te Papa has made, and gives insight into the attitudes and opinions that surround the process. The thesis "Seen But Not Heard? Collecting the History of New Zealand Childhood" by Lynette Townsend is an example of research which focuses on a large and complex subject - childhood - and provides important ground for how I will approach researching the collecting of everyday objects. ${ }^{62}$ Both pieces of research draw attention to how individuals and exhibitions have driven collecting, and provide important context of Te Papa's collecting history.

\section{Summary}

This review began by outlining the importance of the relationship that exists between people and material culture, emphasising how objects are used to create identity and how they may contribute to the writing of history. Material culture can be used by many disciplines and therefore there is much literature to draw from. As this dissertation shows, this is a strength and a weakness. The review then looked at institutional collecting, how museums may collect both now and in the future, and the importance museums play in creating public memory through the objects they choose to collect. Of particular interest here is how gaps in collections can contribute to gaps in memory. In reviewing the literature, it became clear that further work is required to understand how institutions collect everyday material culture. Literature on the future of collecting, by Knell, Pearce, Were, and others, supports my

Smith, "City revealed"; Speer, "Good use"; Keith W. Thomson, Art Galleries and Museums in New Zealand. (Sydney: Reed, 1981).

60 Sean Mallon, "Against Tradition," The Contemporary Pacific 22, no. 2 (2010): 362-38; Kirstie Ross, "Materialising Social History in Museums." Te Ara Journal of Museums Aotearoa 32, no. 1-2 (2007); McCredie, "Collection photographs."; Livingstone, "The History and Development of Foreign Ethnology Collections."

${ }^{61}$ Chloe Searle, "Collecting for New Zealand: Examining What the Museum of New Zealand Te Papa Tongarewa Should Collect," Master's thesis, Victoria University of Wellington, 2010. See also: Matariki Williams, "Ka hao te rangatahi: How is contemporary Māori society collected at Te Papa Tongarewa?" Master's thesis, Victoria University of Wellington, 2014.

${ }^{62}$ Lynette Townsend, "Seen But Not Heard? Collecting the History of New Zealand Childhood," Master's thesis, Victoria University of Wellington, 2008. 
argument. While literature on deaccessioning may provide important context, and while I acknowledge the importance of its inclusion in discussions around museum collections, I understand that there is not enough room in my 20,000 word dissertation to include this topic. I will instead focus on literature on collection building.

There is a gap in research around how museums prioritise items for collecting, exactly how they collect in practice (and not just in theory), and the attitudes curators have towards this. As identified by Gardner, we need more research that approaches collecting from an internal 'on-the-ground' perspective. This review demonstrates that there is much scope to draw on existing literature about the future of collecting, in order to provide new insights into everyday material culture in museums. However, it also calls for a practical approach, focussing on what museums may do at an operational level so that they may contribute to creating and shaping public memory in the future.

\section{Research design}

The literature review revealed that further work is required to understand how museums plan their collecting, and how they collect everyday material culture. While theory on the future of museum collecting exists around this, my research takes on a more practical 'on the ground' approach. Through this focus on current professional practice approach I was able to examine what museums are currently doing to collect everyday material culture, and the implications of this practice.

In order to ensure I effectively addressed the research questions, I undertook qualitative research using a multi-method approach. According to Denscombe, qualitative and case study research characteristically involves a holistic view, which takes place in a natural setting and can utilise multiple research methods. ${ }^{63}$ Museum theory, document analysis, interviews and observation have all contributed to my research. Using Te Papa as a case study narrowed down my focus to a realistic scale, while also enabling me to investigate my research questions with the level of depth they required. Denscombe states that using the case study approach is most appropriate when the researcher wants to 'investigate an issue in depth and will 'provide an explanation that can cope with the complexity and subtlety of real life

\footnotetext{
${ }^{63}$ Martyn Denscombe. The Good Research Guide: For Small-Scale Social Research Projects, (Maidenhead, England: McGraw-Hill/Open University Press, 2010), 55.
} 
situations. ${ }^{64}$ While it might have been sensible to do a comparison with another museum, practicalities like time and word-count limited the scale of my research. Through observation, ethnography also informed part of my methodology. This was especially the case in that I intended to spend time 'in the field. ${ }^{, 65}$ Ethnography is appropriate for this element of the study, as it allowed me to witness collecting and attitudes towards collecting firsthand. Overall, the aim of this multiple method approach was to show changes over time to the collecting of everyday material culture at a practical level. It gives an idea of what has happened in the past, what is happening now, and how it may change in the future.

\section{Methodology}

For my research, I will used the following methods:

1) Document analysis

2) Interviews

3) Observation

These methods are outlined below.

\section{Document analysis}

In order to gain an understanding of how Te Papa approaches collecting, document analysis was used in my research. Documents can refer to many different types of written sources, such as government publications, newspapers, records and diaries, but can also refer to visual sources like photographs and artefacts, and sounds, such as music and recordings. ${ }^{66}$ Denscombe does warn that no document should ever be accepted at face value, and that their validity needs to be established rather than assumed. ${ }^{67}$ As there are a number of government publications, policies and documents that have informed Te Papa's collecting methods, it was important that I became familiar with them. I examined Te Papa's current collection policy and other surrounding documents. This was in order to gain a wider understanding of the fundamental collecting process, removed from individual's thoughts and feelings. This told

\footnotetext{
${ }^{64}$ Denscombe, The Good Research Guide, 54.

${ }^{65}$ Denscombe, The Good Research Guide, 80.

${ }^{66}$ Denscombe, The Good Research Guide, 216.

${ }^{67}$ Denscombe, The Good Research Guide, 221.
} 
tell me what, on paper, Te Papa should be collecting, before moving on to the interviews with curators.

\section{Interviews}

It was important that as part of my research, I was able gain insight into the opinions of curators responsible for the development of Te Papa's collections. Because of this, the most appropriate method to use was in-depth qualitative interviews. Denscombe states that interviews are best used when the researcher wants to gain insights into things such as 'people's opinions, feelings, emotions and experiences. ${ }^{68}$ In particular, in-depth interviews can lend themselves well when the collection of data is based on privileged information. ${ }^{69}$ It is in this case where interviews provide 'value for money' as speaking to key players in the field can provide more depth of information. ${ }^{70}$

I interviewed four Te Papa curators who are directly involved in the building of Te Papa's collections. Given time constraints, I believed I should limit the number of interviews to four. Recruiting curators for interviews was done through my secondary supervisor, via email. I approached four curators at Te Papa with an abstract of my research proposal.

The interviews took the form of one-on-one interviews and were approximately 45 minutes to an hour long, with one exception of 25 minutes. They were semi-structured in order to give both the interviewee and myself the opportunity to explore further should the need arise. As well as taking notes, I recorded all of the interviews using a voice recorder. I did this only with the participant's permission and offered to provide summaries of the recordings should they choose. The interviews meant that I was privy to information, thoughts, feelings, and opinions I would not have had access to otherwise.

Questions were developed using Searle's list of questions from her dissertation 'Collecting for New Zealand' as a starting point. The first interview became a 'test run' for the questions, and remained unchanged for the other three interviews. In retrospect, I would have placed more emphasis on the word 'everyday' throughout the questioning, as curators often got sidetracked, and many of my opening questions did not directly refer to the everyday.

\footnotetext{
${ }^{68}$ Denscombe, The Good Research Guide, 173.

${ }^{69}$ Denscombe, The Good Research Guide, 174.

${ }^{70}$ Ibid.
} 


\section{Observation}

Observation was another method I used as part of my research. Denscombe states that observation does not rely on what 'people say they do, or what they say they think. Instead it draws on the direct evidence of the eye to witness events at first hand ${ }^{71}$ This was especially important in order to gain some insight into what kind of priorities, if any, everyday objects are given when they come up alongside traditionally more 'important' objects, such as works of art. This part of my research strategy involved using the framework of ethnography. The use of reflexivity in my work and research was important here. An element of awareness and openness about my findings, and how I reached my conclusions would be crucial.

Denscombe states that for ethnographers, the conceptual tools used to understand the events being studied, 'are not, and can never be, neutral and passive instruments of discovery. ${ }^{, 72} \mathrm{~A}$ strong example of ethnographic analysis is Sharon MacDonald's Behind the Scenes at the Science Museum, in which she tracks the history of an exhibition, examining how exhibitions are created and how public culture is produced. ${ }^{73}$ Closer to home, is Tanja SchubertMcArthur's PhD study. Here, Schubert-McArthur undertakes an ethnographic study, comprising twelve months of fieldwork, observations, and interviews in order to better understand how biculturalism works in practice at Te Papa. ${ }^{74}$ These are both good examples of what can be learnt, and how research can be strengthened, when observing events first hand.

I sat in on, and took notes at, two of the History and Pacific Cultures team acquisition meetings. This was a critical way to gain insight into how Te Papa collects, and opinions surrounding the importance and prioritising of collecting everyday objects. This also allowed for me to gain some insight into how other departments in Te Papa view the collecting of everyday objects. While the observations I made are not cited widely in my following research, they did provide me with valuable insight, and context that I would not have had otherwise.

I was aware that through the interviews and observation, my research involved using human subjects. As such, I needed to obtain ethical approval from relevant ethics committees before

\footnotetext{
${ }^{71}$ Denscombe, The Good Research Guide, 196.

${ }^{72}$ Denscombe, The Good Research Guide, 86.

${ }^{73}$ Sharon MacDonald, Behind the Scenes at the Science Museum, (Oxford New York: Berg, 2002).

${ }^{74}$ Tanja Schubert-McArthur, ""Walking the Talk"? An Ethnography of Biculturalism at Te Papa." PhD thesis, Victoria University of Wellington, 2014.
} 
I began. I gained the informed consent of those who participated in my research, ensuring that the consent was given voluntarily and that the participants were fully informed of what the research was that I was undertaking.

\section{Reflexivity}

I used reflexivity throughout the stages of my research in order to stay as open and transparent about my research as possible. Denscombe speaks of the inclusion of the researchers 'self' when interpreting qualitative data. He states that, 'the researcher's identity, values and beliefs cannot be entirely eliminated from the process. ${ }^{75}$ Because of this, he believes that analysing qualitative data calls for a reflexive account by the researcher. He advises to keep an open mind, to avoid neglecting data that does not fit the analysis, and to check rival explanations. ${ }^{76}$ He also urges the researcher to remain open to the idea of having 'got it wrong' suggesting that this is in fact fundamental to the production of knowledge. ${ }^{77} \mathrm{I}$ took Denscombe's advice above, by keeping an open mind, and not ignoring data that does not fit with the rest.

Following this introduction, this dissertation is divided into three chapters. The first chapter provides an analysis of the documents Te Papa use to inform their collecting. Chapter Two then focuses on the collecting processes from a practical viewpoint. It provides an explanation of how Te Papa source the material they collect, and follows the acquisitions process curators must undertake to accession an object into the collection. What follows is an examination into what curators look for in an object they are collecting and some of the issues they identify when collecting everyday material culture. Chapter Three then addresses the implications of the findings in Chapters One and Two. It highlights the importance of collection planning, while also examining some of the issues that surround it.

\footnotetext{
${ }^{75}$ Denscombe, The Good Research Guide, 302.

${ }^{76}$ Denscombe, The Good Research Guide, 303.

${ }^{77}$ Ibid.
} 


\section{Chapter One:}

\section{"From the mundane to the iconic"}

As discussed in the literature review, there is an increasing argument for the importance of museums to develop clear and concise documents that outline how and why they collect what they do. In order to better understand how Te Papa collects everyday material culture, this chapter outlines the various documents that contribute to Te Papa's curatorial practice. After an overview of Te Papa's background, the chapter goes on to discuss the collecting documents that are currently in place. The analysis of these documents allows insight into how and why collection decisions are made. It also provides important background information to the research discussed in later chapters as they shape how collecting takes place at Te Papa.

\section{The Museum of New Zealand Te Papa Tongarewa}

Te Papa was opened to the public in February 1998. Incorporating the old National Museum and the National Art Gallery, Te Papa opened with the hope of distancing itself from any negative associations with "stuffy museums," and instead advertised itself as belonging to everybody, a place "where New Zealand was to be defined, celebrated, and shown off, where New Zealanders would find themselves represented." ${ }^{, 78}$ From its conception, Te Papa's main focus was to be of and for the nation and its place in the Pacific. ${ }^{79}$ The museum was tasked with trying to bring all its peoples closer together, while simultaneously catering for its many international visitors.

Bain Attwood identifies Te Papa's desire to reflect biculturalism as one of the key challenges the museum faced from its conception. ${ }^{80}$ This emphasis on biculturalism meant that the Treaty of Waitangi was "regarded as the conceptual centre of the museum." 81 Almost twenty years after opening to the public, its website states that Te Papa is "renowned for being

\footnotetext{
${ }^{78}$ Charlotte Macdonald, “Two peoples, one museum: Biculturalism and visitor 'experience' at Te Papa Our Place, New Zealand's new national museum.” In Contested histories in public space: Memory, race, and nation, edited by D. J. Walkowitz \& L. M. Knauer, (Durham and London: Duke University Press, 2009), 44.

${ }^{79}$ Bain Attwood, "Difficult Histories: The Museum of New Zealand Te Papa Tongarewa and the Treaty of Waitangi," The Public Historian, 35, no. 3 (2013): 54.

${ }^{80}$ Attwood, "Difficult Histories," 55.

${ }^{81}$ Attwood, "Difficult Histories," 56.
} 
bicultural, scholarly, innovative, and fun," where their success is built on "our relationships with and our ability to represent our community." ${ }^{82}$ However, Te Papa's approach to biculturalism has been questioned by academics from as early as 1999. In terms of objects on display, historian Charlotte McDonald criticised the museum's failure to accurately depict Māori and Pakeha through intertwined histories. ${ }^{83}$ She argues that this is due to the focus on the nineteenth century for Māori exhibitions, and twentieth century for the history exhibitions: "The implication that "history" belongs to Pakeha and "culture" to Māori is one that can be drawn." 84 As we will see in Chapter Three, this has implications for the collection of everyday material culture.

Te Papa is a Crown entity that operates under the Museum of New Zealand Te Papa Tongarewa Act 1992. It receives funding from central government in order to carry out the functions as stipulated in the Act. In terms of collection development, in the 2015/16 financial year Te Papa received \$29.574 million in funding from the Government, with another \$26.569 million coming from non-Crown sources. Of this, \$3.697 million was spent on new acquisitions. The Museum of New Zealand Te Papa Tongarewa Act 1992 establishes Te Papa's purpose to provide a "forum in which the nation may present, explore, and preserve both the heritage of its cultures and knowledge of the natural environment in order better -

(a) to understand and treasure the past; and

(b) to enrich the present; and

(c) to meet the challenges of the future." 85

Section 7 of the Act provides the mandate for Te Papa to develop collections. This section lists collecting as one of the principal functions of Te Papa. It states that Te Papa is required to "collect works of art and items relating to history and the natural environment" and to "develop, conserve, and house securely the collections of art and items relating to history and the natural environment in the Board's care." ${ }^{\prime 86}$

\footnotetext{
82 “About Mō mātou - Museum of New Zealand Te Papa Tongarewa.” Accessed February 6, 2017. https://www.tepapa.govt.nz/about

${ }^{83}$ Macdonald, "Two peoples, one museum," 37.

${ }^{84}$ Ibid.

${ }^{85}$ Museum of New Zealand Te Papa Tongarewa Act 1992 s 4

${ }^{86}$ Museum of New Zealand Te Papa Tongarewa Act 1992 s 7.1 b \& d.
} 
The Act states that when performing its functions, including collecting, Te Papa will:

- "have regard to the ethnic and cultural diversity of the people of New Zealand, and the contributions they have made and continue to make to New Zealand's cultural life and the fabric of New Zealand society."

- "endeavour to ensure both that the Museum expresses and recognises the mana and significance of Māori, European, and other major traditions and cultural heritages, and that the Museum provides the means for every such culture to contribute effectively to the Museum as a statement of New Zealand's identity,"

- "endeavour to ensure that the Museum is a source of pride for all New Zealanders."

Overall the Act, and in particular Section 7 of the Act, establishes that collecting is fundamental to Te Papa in fulfilling its role as the national museum. It also sets out broad parameters for the purposes of their collecting, with an emphasis placed on contributing to the creation of national identity.

\section{Collecting policies}

The year 2016 saw changes made to Te Papa's collecting processes with the introduction of a new Collections Policy and the major overhaul of the Acquisitions Strategy, a document which was in theory renewed every three years and sat between the Policy and the Acquisitions Plan. While the Policy is long-term, setting out a number of core principles for Te Papa's collections, the Plan is revised every year and is developed by and specific to each collecting department. Below is a brief analysis of these documents.

\section{- Collections Policy (2016)}

Te Papa's current Collections Policy covers the acquisition, care, management, use and deaccession for all of Te Papa's collections. It replaces several earlier policies by merging them into one, namely, the Collection Development Policy (2007), Collection Management Policy (1992) and Conservation Policy (1992). In terms of collecting, the Policy sets out Te Papa's commitment to, "collect items/taonga relating to art, history, cultures, and the natural environment that will enable Te Papa to fulfil its legislative mandate." 88

\footnotetext{
${ }^{87}$ Museum of New Zealand Te Papa Tongarewa Act 1992 s 8a, b \&c.

${ }^{88}$ Museum of New Zealand Te Papa Tongarewa, Collections Policy 2016, s 1.2.1.
} 
A number of core principles are included in this document in order to guide Te Papa in its role of "collecting for the nation." 89 These principles are extremely important in outlining the kind of collecting Te Papa should be doing and place a significant amount of emphasis on collecting for New Zealand and New Zealanders. This includes, "Our national collections will be representative and inclusive of all New Zealanders, to show the nation at all socioeconomic levels, and to demonstrate and explore New Zealand values," and "Te Papa's collections will ... represent New Zealand and its peoples to the world." ${ }^{90}$ As a result, collecting is expected to be national and/or international in scope and significance, and there is no mention of collecting locally. ${ }^{91}$ The acquisition of everyday material culture could be justified though the inclusion of the line "all socioeconomic levels". This enables curators to carry out social history collecting 'from below' in order to better represent New Zealanders from all walks of life.

The emphasis on collecting only objects that carry national significance is outlined clearly when the Policy states: “Te Papa will collect items/taonga relating to art, history, cultures, and the natural environment to develop collections of nationally significant aesthetic, historical, cultural, and scientific value." $" 92$

Objects collected by Te Papa are expected to have significance in more than one thematic area and, "represent a range of cultural value, historical experiences, artistic merit and scientific integrity." 93 The five core thematic areas Te Papa actively collect in are:

- Mātauranga Māori histories and cultures

- The unique natural environment of New Zealand and people's interaction with it

- Art and design, particularly the art of Aotearoa New Zealand and the Pacific in a regional and global context

- The culture of Pacific peoples in New Zealand, the Pacific rim and in their contemporary locations;

- New Zealand histories, cultures and people in a national and global context. ${ }^{94}$

\footnotetext{
${ }^{89}$ Collections Policy 2016, s 2.1 .

${ }^{90}$ Collections Policy 2016, s $2.2 \& 2.5$

${ }^{91}$ Collections Policy 2016, s 2.4.

${ }^{92}$ Collections Policy 2016, s 3.1.

${ }^{93}$ Collections Policy 2016, s 2.9.

${ }^{94}$ Collections Policy 2016, s 2.8.
} 
Section 3 of the Policy covers acquisitions and outlines how and what Te Papa should be collecting. In order to acquire items for the collections, "due diligence" is expected to be carried out and documented. This involves:

- Research to determine the national significance of the objects.

- Expert assessment to determine the objects are in a state that will "enable the realisation of their intended use and significance."

- Objects are acquired only when Te Papa is able to care for and manage them.

- Legal title is established for every object, and confirmation is sought that the original collecting was legal and ethical.

- All objects meet internal and external audit requirements. ${ }^{95}$

While the 2007 Collection Development Policy did focus on collecting the nationally significant, this is much more explicit in the new 2016 Policy. The terms national, New Zealand, New Zealanders, and significance are used many times throughout the document. Most notably for this research, there is a line from the 2007 Policy that has not been included in the 2016 Collections Policy: "The concepts for representativeness and significance guide the consideration of items for acquisition by Te Papa ... including ... securing the full range of items from the mundane to the iconic." ${ }^{96}$ As the 2016 document now covers collection development, collection management and conservation, it is also considerably lighter and no longer includes any attempt at defining what 'nationally significant' objects might look like. Howver, the Acquisition Strategy usefully provides more specificity.

\section{- Acquisition Strategy}

The Acquisition Strategy sets out the desired outcomes, approaches and priorities for Te Papa's collection development. Up until 2016, it was designed to operate over a period of around three years and was often rolled over without any changes. The strategy was aligned with Te Papa's Vision: "Changing Hearts. Changing Minds. Changing Lives." 'everyday' is used twice in the 2015/16 strategy. First, in the strategic approach it states that Te Papa will collect "a range of items across the spectrum of each field (for example, from

\footnotetext{
${ }^{95}$ Collections Policy 2016, s 3.6.

${ }^{96}$ Musuem of New Zealand Te Papa Tongarewa, Policy on Collection Development at Te Papa 2007, s 1.4.

${ }^{97}$ Museum of New Zealand Te Papa Tongarewa, Draft Acquisitions Strategy 2015/16, 1.
} 
folk art to high art, from the everyday to the ceremonial, and from the mundane to the iconic.) ${ }^{98}$ Secondly, it is listed as an acquisition priority for the collecting area of New Zealand History and Heritage, stating that acquisitions will include "items that reflect aspects of everyday life in New Zealand." 99 Up until 2016, this document was the primary document used and cited by curators when justifying acquisitions and their relevance to the policy or strategy. As of 1 February 2017, 674 out of 2098 approved history proposals catalogued on KE EMu used the term 'everyday' (in the relevance to policy/strategy field) as a rationale for collecting. This comes to a total of $32.1 \%$ of the history collection, meaning that around a third of Te Papa's history collection falls under the category of 'everyday'. 100

Currently, Te Papa is in the process of drafting a new document to replace the Acquisition Strategy. The new document, titled Collection Strategy, will be in place from 2016 until 2021. It differs from the old acquisition strategies in that it focuses not only on collection building, but on reviewing its current collections. Key outcomes for the strategy include:

- Continue to building collections of national significance

- Better strategise collecting activity so it is focussed, rather than comprehensive

- Deepen the understanding in depth of what we have

- Look for items of low value, duplication and items that no longer fit with our strategic approach

- Build collections based on research and scholarship. ${ }^{101}$

From these outcomes, we can see how Te Papa is now moving to focus on not only adding to its collection, but also on assessing what it already has, and how it may best use it. After the key outcomes are identified, an assessment of collection relationships both internally and externally (with other institutions such as Alexander Turnbull Library) is proposed before the areas of review to be staggered over the next five years are listed. It is then broken up into the five main collecting areas where it is further broken up into the following categories: key outcomes, SWOT analysis of the collections (strengths, weaknesses, opportunities, threats), development priorities, priorities for collecting, opportunities to leverage the collection,

\footnotetext{
${ }^{98}$ Draft Acquisitions Strategy 2015/16, 2.

${ }^{99}$ Ibid.

${ }^{100}$ Kirstie Ross, "Collecting everyday material culture: Analysing KE EMu, Te Papa's Collection database," February 2, 2017, text file, 3 .

${ }^{101}$ Museum of New Zealand Te Papa Tongaerwa, Te Papa Collection Strategy 2016-2021, 1.
} 
opportunities for digitisation, and areas for review. The opportunity for collecting everyday material culture, in a more targeted way, can be identified in the New Zealand History priorities for collecting: "Develop focussed collecting strategies around the social and cultural history of the national life of sport, religions and faith, popular culture, children and youth and work to support renewal in the first instance."102

This is a far more detailed strategy than the previous acquisition strategies, and provides staff with a document that takes a step back and looks at Te Papa's collections as a whole, encouraging constant and active reviewal.

\section{- Acquisitions Plan}

The Acquisitions Plan is a working document that covers all five of the core thematic areas of Te Papa's collecting: Art, New Zealand History and Heritage, Natural History, Pacific Cultures, and Mātauranga Māori. It is produced annually and includes plans to "review a section of the current collections in order to ensure their ongoing relevance." ${ }^{\prime 103}$ Unlike the Policy document, the Acquisitions Plan identifies specific items, opportunities, or collecting categories that would be acquired that year. ${ }^{104}$

The Acquisitions Plan contains confidential and commercially sensitive information, and as a result is for internal use only. Currently, there is no Acquisition Plan to view, while teams wait for the Strategy to be reviewed and approved. However, I was able to see the 2015/16 Plan. The Plan is broken down into five sections which cover the collection areas. Each section contains an overview with a short summary of what each team is responsible for and a brief discussion of their main focus areas for collecting. It is then broken down into categories including prioritised acquisition areas, themes, projects, and archives, among other things. It also includes brief statements about establishing key community relationships, and takes into account other collecting institution's interests. Throughout the document, gaps in collections are also identified with the ultimate goal being to fill them. Many of the prioritised acquisition areas listed include the potential for the collecting of everyday material culture, in particular the area of "cultural and social diversity of Aotearoa New Zealand.".105

\footnotetext{
102 Ibid.

${ }^{103}$ Collections Policy 2016, 7.1.1.

${ }^{104}$ Museum of New Zealand Te Papa Tongarewa, Acquisitions Plan 2015-16, 1.

${ }^{105}$ Acquisitions Plan 2015-16, 6-7.
} 
The goal of the Acquisitions Plan is to identify gaps in current collecting, and establish new strategies for collecting. It ranges from broad ideas around collecting themes to identifying specific objects that are missing from the collection. It differs from the Collections Policy in that it is much more specific in listing how each team intends to develop their collections. The curators interviewed had little to no input into the development of the collections policies, although they were offered the opportunity to provide feedback for the 2016 Collections Policy. For the yearly Acquisitions Plans, the curators have much more input, due to the specificity of the document. The Plan was described by one curator as "the most useful document" and is much more likely to be used on a day to day basis due to the targeted aims identified in the Plan. ${ }^{106}$

\section{Summary}

This chapter analysed the documents that set out Te Papa's collecting practices. Starting broadly with the Act, and working down into more specific collecting goals within the Acquisitions Plan, we can see how these documents shape the everyday collecting at Te Papa. While the policy document provides the principles for Te Papa's collecting, the plan enables each department within Te Papa to focus their collecting. The move from a detailed Policy document (2007) to a broader one (2016) which incorporates several pieces of collections policy, shows a move to simplifying how Te Papa collect. The removal of the line "securing the full range of items from the mundane to the iconic" from the Policy, and the complete reworking of the strategy means that curators now have three layers of criteria to work to. Exactly what this may mean for the future of collecting everyday material culture is as yet unknown.

\footnotetext{
${ }^{106}$ Interview with Curator Four, October 17, 2016. Unless otherwise stated, hereafter all quotes come from the interviews listed in the bibliography.
} 


\section{Chapter Two: \\ Collecting everyday material culture at Te Papa}

Chapter One analysed the various policy and strategy documents Te Papa staff use to build their collections and the ups and downs of everyday material culture as a collecting priority in those documents. This next chapter examines how Te Papa curators collect everyday material culture in reality as opposed to on paper. First, there is an examination of several successful acquisition proposals for everyday material culture objects now held in Te Papa's collection and how these types of objects have been used for exhibition. The chapter then examines how curators source the objects they collect. The process of acquiring these items is described before moving on to a discussion about how curators make decisions about what to collect, how everyday material culture is viewed by curators and how it is justified in Te Papa's collecting practices.

\section{Te Papa's existing everyday material culture}

Before analysing how Te Papa's curators collect everyday material culture, we must first examine what already exists in the collection. While there remains an unknown number of collections not yet catalogued on Te Papa's database, KE EMu is a good start in understanding everyday material culture's presence in their collections. KE EMu contains a total of 5025 authorised acquisition proposals, with 2098 having been submitted by the history team. ${ }^{107}$ A total of 737 proposals used the term everyday/every day as justification for collection, with 674 of these belonging to the History team. ${ }^{108}$ This means that approximately $32.1 \%$ of the History collection that is catalogued on KE EMu is made up of objects of everyday material culture.

\section{Acquisition proposals}

In order to understand how everyday material culture has been collected in the past I reviewed a number of acquisition proposals. Below is an analysis of five successful

\footnotetext{
${ }^{107}$ Ross, "Collecting everyday material culture" report. Figures accurate as of February 1, 2017.

${ }^{108} 674$ of these proposal came from the History team, 68 from the four other collecting areas (art, science, Pacific cultures, Mātauranga Māori). Some proposals will use more than one criterion from the strategy.
} 
acquisition proposals put forward by curators at Te Papa. Four are for individual objects, and one is for a collection of multiple objects from one individual. All objects are held in the History collection, except for the ball of thread which is part of the Pacific collection. These proposals were chosen in two ways, through random searching of Te Papa's online collections on their website and by recommendation of Kirstie Ross as "good examples of everyday material culture." The Andrea Hill collection was suggested both in conversation with Kirstie Ross, and by members of the History and Pacific teams, following my observation of their acquisitions meeting. These four objects, and one collection, which were collected at different times by different curators, show how acquisition proposals are shaped by curators in order to successfully collect an object.

\section{Bag}

Reg. No. PC003116

Maker unknown, dated 1913-1914.

This object, a brown suede bag, was collected in 1984 along with some leather artificial flowers and a leather leg garter. Beyond the details of the donor and the date acquired, there is no more information held by Te Papa on these objects. Nothing is held on KE EMu, and there are no physical object files. In an email enquiring about object files for the bag, the respondent stated that the "very early [objects] rarely do.",109

It is unfortunate that there is often no written justification given to the earlier objects. It is perhaps because of these objects, that a paper trail and appropriate justification is now necessary for all objects now acquired by Te Papa.

\section{Andrea Hill collection ${ }^{110}$}

This acquisition, separated out into two different proposals, was put forward for consideration in 2008 and authorised in 2009. Together, they contain 264 objects. The first proposal contains a number of social history and popular culture objects from the mid to late twentieth century including kitchenware, children's games, and toiletries. The second is

\footnotetext{
${ }^{109}$ Sara Guthrie, email message to Kirstie Ross, October 4, 2016.

${ }^{110}$ Stephanie Gibson, “Acquisition Proposal 2851 - Andrea Hill collection.” Museum of New Zealand Te Papa Tongarewa, February 29, 2008; and Stephanie Gibson, “Acquisition Proposal 2852 - Andrea Hill collection.” Museum of New Zealand Te Papa Tongarewa, February 29, 2008.
} 
made of up ephemera from significant life rituals such as $21^{\text {st }}$ birthdays, marriage, and wedding anniversaries.

\section{- Justification}

The significance of the overall collection is argued by the curator through three main points. These being that it will fill gaps and augment current holdings, that it is in good condition, and that it has very good provenances. Also argued in the second acquisition proposal, is that the collection of ephemera related to life rituals provides useful research depth and that the graphic designs act as an interesting record of fashion and attitudes towards ritual in the 1950s.

This collection contributes to the Acquisition Strategy 2007/08 statement under New Zealand History and Heritage: "items that reflect aspects of everyday life in New Zealand." In terms of collection relationships, the curator argues that while there are allied objects in the collection, "generally our holdings of such material is poor and fragmentary." While the curator acknowledges that there are a number of wedding dresses held in the collection, they argue that there is a lack of the ephemeral material that accompanies weddings and marriage. For use in scholarship, the objects lend themselves to research on expressions of group identity and material life in Aotearoa New Zealand.

Each object is listed and along with dates and dimensions, includes detailed provenances and an explanation as to why the object is significant.

\section{- Collection management and conservation}

Storage space was available for this large acquisition and, by and large, each item was in good condition.

\section{Ball of thread ${ }^{11}$}

Reg. No. FE012484/a

Rose Brand ball of yellow cotton thread. Made in China. Text on black sticker reads: Cotton pearl, Rose brand, 8, 10 grams, 95 yds, Shanghai China.

\footnotetext{
${ }^{111}$ Safua Akeli, "Acquisition Proposal 3072 - Collection of tivaevae, cushion covers, and tivaevae-making ephemera.” Museum of New Zealand Te Papa Tongarewa, September 26, 2008.
} 
This object is part of a larger collection consisting on 21 items. The collection includes tivaevae, cushion covers, and tivaevae-making ephemera and is part of the Pacific collection. The acquisition was authorised in May 2009, after being recommended in September 2008. Unlike the other objects listed here, this collection was purchased by Te Papa.

\section{- Justification}

The justification of this acquisition focusses on the collection as a whole, instead of each individual object. The thread, alongside the other objects included in the collection, make an important contribution to the Pacific collection as examples of tivaevae and tivaevae making in New Zealand from the 1960s. Unlike the proposals for the Mac Plus manual and television below, the 'Significance for Collection' section of the 2009 Pacific acquisition proposal is kept brief. While the significance is argued, no background information is given as to where the collection has come from, and there is no personal story given. Provenance is given later in the proposal however, listed under each individual object (offered for sale by the daughter of the original owner).

In terms of collection relationships, this collection contributes to an already existing collection of around thirty tivaevae. The ball of wool and other tools act as "important examples of tools used in the making of tivaevae." ${ }^{\prime 12}$ For scholarship purposes, the collection is able to contribute to research on tivaevae making in New Zealand. And for exhibition programmes, could be used for modern tivaevae exhibitions and also educational programmes about the making of tivaevae.

\section{- Collection management and conservation}

In the proposal, space for storage of the thread is agreed upon. The thread is in good condition, as identified by a conservator, but there is need to do work on the label during storage to barrier from dyed cotton.

${ }^{112}$ Akeli, “Acquisition Proposal 3072," 2. 


\section{Television set (black and white) ${ }^{113}$}

Philips Electrical Industries black and white television set standing on four tapered legs. Wooden veneer cabinet with plastic controls along the bottom. Model 23CZ 501A. Serial no. 7636.

Reg. No. GH021008

This television is an example of local manufacturing, having been built in New Zealand. It was offered for donation by the son of the original owner when he was clearing out her home in 2009. The acquisition was authorised two years later in February 2011.

\section{- Justification}

The curator highlights the significance of the television set as both for the object itself, and for the story of the owner that comes with it. Firstly, the object is significant as it is an "example of locally manufactured broadcasting technology and enterprise, made by a wellestablished electronics firm." 114 Secondly, the curator highlights the object's connection to a personal story related to immigration in New Zealand. The television set was purchased by an immigrant whose family "were conscious of making the most of their new home and worked hard to attain a lifestyle that would have been impossible" in their home country. ${ }^{115}$ She worked at Philips Electrical and purchased the set in 1966, when only around $16 \%$ of the population owned a television.

Minor significance as an example of design and how televisions (and radios) have been treated as domestic furniture is also included in the justification section of the acquisitions proposal.

In terms of relevance to the Acquisitions Strategy (2008/09), the object fits into two criteria: items that "illustrate the diverse cultural heritage of New Zealand" and items "that reflects aspects of everyday life in New Zealand."116 The object joins three other television sets, as well as a Philips manufactured radio, already held in the collections.

\footnotetext{
${ }^{113}$ Kirstie Ross, “Acquisition Proposal 3528 - Philips black and white television set.” Museum of New Zealand Te Papa Tongarewa, January 6, 2011.

114 Ross, "Acquisition Proposal 3528," 4.

115 Ibid.

${ }^{116}$ Ibid.
} 
For scholarship purposes, the curator believes that the item is useful to anyone researching local manufacturing, the electronics industry, and the history of broadcasting in New Zealand, as well as personal stories about immigration.

The curator offers up a number of suggestions for the way in which this television set may be used for exhibitions. The object could be used in any programme related to the television and broadcasting history of New Zealand, of local manufacturing, and the events and products concerned with immigration to New Zealand.

\section{- Collection Management}

The Collection Manager that assessed the object notes that Te Papa already hold a 1960s black and white Philips-made television. However, she states that the item that already exists in the collection has little provenance. This again emphasises the importance of context, and the prioritisation of collecting an object which has provenance.

\section{Mac Plus computer guide ${ }^{117}$}

Reg. No. GH021816

Boxed set of operating instructions for the Apple Macintosh Plus computer ('Mac Plus') Includes:

1 - Box titled 'Macintosh Plus'

2 - Spiral bound instruction manual

3 - Tape cassette titled 'A Guided Tour'

4 - Disc titled 'System Disk'

5 - Disc titled 'A Guided Tour'

6 - Brown plastic insert for disk cavity

7 - Warranty statement

This object was created by Apple Computer in 1986 and was produced in the United States. It was approved at History \& Pacific Acquisitions Meeting held on 20 September 2011 and later authorised for collection in February 2012. It was acquired through donation.

\footnotetext{
${ }^{117}$ Stephanie Gibson, “Acquisition Proposal 3848 - Mac Plus computer guide,” Museum of New Zealand Te Papa Tongarewa, December 21, 2011.
} 


\section{- Justification:}

Several points are argued as to why this specific computer guide has significance for the collection. It is broken down into two sections. The first relates directly to the object and why it's important to the collection, while the second paragraph contextualises the object and argues for its national significance. The first argument provided by the curator, is how the object illustrates how innovative the computer was at the time. The second argument is around how the object demonstrates the level of technology during this period of the 1980s due to the inclusion of cassettes and discs. Unlike the first point around innovation, this argument relates directly to how the instruction manual is significant, as opposed to the computer that the manual is for. The last argument provided by the curator is that the item is significant because it completes the Mac Plus computer Te Papa had collected earlier.

In terms of national significance, the curator first places the object with a national context before moving on to international significance. The Mac Plus, which this manual supported, was the first computer to be used by the Department of Education to publish educational material included the School Journal. Internationally, the curator argues, this item 'represents international shifts and trends in computer technology and industrial design, and their impact on New Zealand.' ${ }^{118}$

The curator links the objects to the 2010/11 Acquisitions Strategy, "Items that reflect aspects of everyday life in New Zealand; and historical ... design that relates to New Zealand," before linking the items to several computers already held in the collections.

Finally, the curator lists the exhibition potential the object has. Included in this is exhibitions on publishing, social history of technology and computing, education, and industrial design.

\section{- Conservation and Collection Management}

The discs and cassettes which belong to the Mac Plus manual are kept to be examples only, and are not intended to be used. Masters and playability is therefore not an issue, due to the fact that much of the information that exists on the discs and cassettes can also be found in the printed manual. This means that the items are able to be stored together as one unit

118 Gibson, “Acquisition Proposal 3848," 2. 
instead of separated out for preservation reasons. The conservator notes that while there is some wear and tear and some rusting, the object is in fair to generally good condition.

\section{What do these proposals tell us?}

These proposals show us that in order for an object to be collected it must meet a number of criteria. The curator must justify why an object is significant for the collection, how it can be used in exhibitions and in scholarship, how it relates to the collection policy (or strategy) and any collection relationships the object may have. After that, storage and preservation is taken into account and assessed by a collection manager and a conservator. A valuation is given, and costs are taken into account including any extra costs, such as storage and conservation. In the 'significance for collection' category of the acquisition proposals, we can see how curators build their argument for an object. The objects are often linked not only to their wider, national significance, but where possible, to a personal story as well. This shows us that curators value the stories that come with the objects.

The ball of thread tells us that smaller and perhaps more mundane objects are still considered important for collection. We are also able to see how acquiring objects has changed over time, and how the process has become more and more robust. The bag which was collected in the 1980s had no information available about why it was collected whereas the television set collected in 2011 has a detailed record of provenance, with a curator carefully and purposefully justifying its need for collection.

\section{The Slice of Heaven exhibition}

The long term history exhibition Slice of Heaven, about $20^{\text {th }}$ Century New Zealand and the events that shaped it, is an example of how everyday material culture has been used by Te Papa and how it may successfully contribute to public museum display. Opening in 2010 and running for six years, the exhibition featured a huge number of social history objects. The exhibition was divided into four main sections: international relations, social welfare and the state, Māori in the $20^{\text {th }}$ century, and diversity and civil rights. Objects feature heavily throughout, and are used to tell stories about New Zealand history. 
Running through the middle of these sections, covered in plastic bright green grass, was a fifth section titled 'Home-grown'. This section was filled with everyday objects that would have populated many New Zealand homes from 1900 to $2000 .{ }^{119}$ Objects were clustered together in display boxes according to which decade they belonged in. Some would feature children's toys, others filled with technology that you would have found in everyone's home, such as telephones and irons. To some extent, many of the objects in each display box remained unlabelled. A card next to each box featured some of the objects you could see on display, but not all. Instead, the opening sign urges visitors to look for themselves and see if they recognised anything, encouraging memories and connections to be made to these objects that would have been part of people's everyday lives. Although it is difficult to gauge people's individual reactions to the everyday objects on display, the summative evaluation for the exhibition revealed that the public had a mixed reaction towards the sense of "fun and nostalgia” 'Home-grown' was attempting to create. Some enjoyed it, and some were confused by its difference to the rest of Slice of Heaven. ${ }^{120}$ However, while I was visiting this particular section of the exhibition, a woman excitedly exclaimed, "I used to have that doll!" Slice of Heaven used everyday objects in such a way that New Zealanders were able to feel connected to the exhibition, and to their place in New Zealand's history.

\section{Sourcing objects for the collection}

Having reviewed Te Papa's existing collections, examined authorised acquisitions proposals, and explored how everyday objects can be used for exhibitions, this next section investigates current practice at Te Papa. There are several ways that curators source objects in order to build Te Papa's collections. The three main ways objects are sourced as identified by the curators interviewed are donations, auctions and purchasing through vendors or individuals. These are discussed in more detail below.

\footnotetext{
${ }^{119}$ It is important to note that the everyday objects on display here were not from the collection. Because the objects were required to be glued down, their display presented conservation issues so props were sourced in their place. However, there are a number of examples of the types of items in the display in the History collection.

${ }^{120}$ Morris Hargreaves McIntyre, "“What it is to be Kiwi' A summative evaluation of Slice of Heaven: $20^{\text {th }}$ Century Aotearoa," September, 2011.
} 


\section{- Donations}

The three history curators interviewed all identified donations as the most common way items, and in particular items of everyday material culture, are collected. This is most likely done through members of the public contacting Te Papa by phone or email, or in person usually in some form of "dump and run" - leaving items at the front desk or by the door. In terms of everyday material culture, objects are often donated by members of the public clearing out their home, or the home of a loved one. Curator One stated, "People consider us to be the nation's attic so they ring and offer us their treasures because they don't want to throw them out and they don't know about their local museum."

The media may also have a hand in encouraging donations, with one curator mentioning having to watch Antiques Roadshow so they would be able to know what type of offers Te Papa would be getting from the public the following week.

Donations mean that there is a relatively steady flow of objects being considered for collection with Curator Four commenting, "I would get a minimum of one email a day but often five a day, of people offering us things, and phone calls." Because of the nature of donations, it means that quite often result in what Curator Four described as 'haphazard collecting': "My experience when I first arrived here was that the team spent their time being reactive and at the behest of phone calls and emails rather than active collecting." James B Gardner highlights this conflict between what he calls "planned" and "passive" collecting, posing the question, "Can collections planning allow for the serendipitous while pursuing carefully worked out documentation strategies?"121

Due to the amount of offers of donation that are made to the history team especially, it makes them the biggest collectors out of the different departments. Curator One commented, "we do collect a lot of volume ... but we're seen as the nation's attic and we get hundreds of offers every year. We only take a fraction of them, but a fraction of them is still a lot." Te Papa's Annual Reports confirm this, with History objects outweighing all other areas of collecting both in terms of new acquisitions and donations. ${ }^{122}$

\footnotetext{
${ }^{121}$ Gardner, "From idiosyncratic to integrated," 215.

${ }^{122}$ See Museum of New Zealand Te Papa Tongarewa Annual Report 2015/16 as an example.
} 
While building the collection entirely and reactively through donations can result in an adhoc style of collecting, it does mean that on occasion something really special will crop up. When speaking about getting a balance between proactive and reactive collecting, Curator Four stated, "the great thing about the donations is people do offer you some quite amazing things ... things that you would not necessarily be looking for."

\section{- Auctions}

Auctions were also identified as another of the major ways the curators at Te Papa source objects for their collections. This would often depend on what area you were collecting in, with decorative arts being identified as the type of object that would often come in through auction.

The point was raised that auctions can be stressful due to their time sensitive nature, with catalogues only turning up a week or so before the auction. Despite this, well-researched and robust proposals and bidding limits must still be approved before the auction. ${ }^{123}$ Curator Two stated, "I despise getting objects through auction... they put you into this false sense of haste." Although the point was raised during an acquisitions meeting, that when it came to obtaining objects, auctions are overall "quicker and cleaner" than negotiating donations or purchases with individuals. $^{124}$

In terms of online auction sites, such as Trade Me, it was identified that Te Papa was yet to position itself in such a way that meant it was easy to purchase from them. Curator Two admitted that they would often buy objects with their own money before beginning the acquisition proposal process, through fear that the slow-moving nature of purchasing through Te Papa would result in them missing out on the object entirely. While this could result in a new acquisition for Te Papa, this is also a risky move on the part of the curator, paying out of their own pocket for an object that is yet to go through the acquisition process.

\section{- Purchasing}

The last main source of collecting objects for Te Papa was through purchasing from individuals or vendors, or it can be commissioned. Purchasing can either be done reactively,

\footnotetext{
123 Topic of discussion at History and Pacific Cultures acquisitions meeting, November 1, 2016.

${ }^{124}$ History and Pacific Cultures acquisitions meeting, November 1, 2016.
} 
by responding to offers made as and when objects come up, or it can be proactive. More often than not, objects of everyday material culture are low value, and therefore do not make up a large portion of Te Papa's yearly acquisitions budget.

\section{Proactive and reactive collecting}

Reactive collecting refers to coming across the chance to collect, peeling a poster off a wall, or stumbling across an interesting item in a second hand shop. Proactive collecting, on the other hand, involves targeted and purposeful collecting. Curator Four talked about the challenge of proactive and reactive collecting, and the importance of finding a balance between the two, "One of the challenges for us, particularly when you're looking for more historical material, is you can't go to an art dealer necessarily ... [the object] might not exist."

Every curator interviewed expressed their preference for proactive collecting:

Sometimes it's reactive, sometimes it's proactive. I'm always keeping an eye out that's the passive reactive way of collecting. Then there is purposeful, intentional, curatorial collecting where you know you are building a body of material culture. (Curator One)

For me it's knowing what part of the collection you're working with well, identifying what is missing, or where you want to expand or flesh out, and then being quite targeted... it's the ideal thing, really. You plan, you do your research so you know who's active, who's interesting, and approach them. (Curator Four)

Some apprehension over active collecting for the sole purpose of display was expressed by the curators. This is likely playing on many of their minds as Te Papa moves into exhibition renewal in the upcoming months. Gardner has highlighted the issues around exhibition-led collecting, warning that it can be limiting to focus on current needs at the expense of the long term. ${ }^{125}$ However he also urges museums to consider whether it is responsible for museums to collect objects they cannot conceive of exhibiting. ${ }^{126}$ The 'Exhibition Programme' section

${ }^{125}$ Gardner, "From Idiosyncratic to Integrated," 217.

${ }^{126}$ Ibid. 
of Te Papa's acquisition proposal requires curators to state what potential the object has for exhibition. This ensures that every object collected has exhibition potential, however it is not necessarily for a specific exhibition, but more generally for the type of exhibition the object could be included in. The acquisition process and proposals are discussed later in this chapter.

Curator One noted that when they began at Te Papa in the early 2000s, they were still collecting under an " $80 / 20$ split" - a hangover from the 1990s and the drive to create new exhibitions for Te Papa's new waterfront location. This arrangement meant that $80 \%$ of collecting was intended to be for exhibition while the other $20 \%$ was for long term collection without any immediate need for exhibition. During this time there was much more concern over whether an object being proposed had exhibition potential. In retrospect, however, this may not have necessarily been the most positive move for Te Papa. Curator Three stated, "At one stage when the Te Papa project was in the exhibition development stage we fell into the trap of exhibition collecting. Good, in terms of that project, but once the exhibition has been taken down, do we really need all these 1940 Centennial Exhibition items?"

In terms of prioritisation, proactive collecting takes priority over unsolicited donations, as stated in the 2015/16 Acquisition Plan. ${ }^{127}$ For the 2015/16 financial year, the History team had a total of 116 new acquisitions approved. ${ }^{128}$ Of this, 88 were donations and only 28 purchased. This is a dramatic difference to the Art collection, who purchased 101 acquisitions out of a total of $127 .{ }^{129}$

Another form of active collecting was identified by one of the Curator Two as "collaborative collecting." Three out of four of the curators interviewed talked about this process as being one of their favoured ways to collect. Curator Two described collaborative collecting as "handing agency back to communities for them to figure out how they want to be remembered." When asked how they envisioned Te Papa's collecting in the future, the same three curators hoped for the process of collaborative collecting to be further developed. Searle's earlier research revealed that the public also wish to have this relationship with Te Papa. If given the opportunity to provide input into deciding what Te Papa should collect, the

\footnotetext{
${ }^{127}$ Acquisitions Plan 2015-16, 6.

${ }^{128}$ Many of these acquisitions are made up of multiple objects.

${ }^{129}$ See Museum of New Zealand Te Papa Tongarewa Annual Report 2015/16.
} 
public felt they could contribute to building collections that were relevant to them. ${ }^{130}$ Exactly what developing collaborative collecting may mean for collecting everyday material culture remains unknown. If most of Te Papa's everyday material culture enters the collection through unsolicited donations, then this may lead to a decrease in it being collected. Collaborative collecting is discussed in more detail in Chapter Three

\section{Acquisitions process}

Once a curator has decided that they want to potentially collect an object, and research into the object has begun, they can put the item forward at the acquisitions meeting. Held every two weeks, the acquisition meeting is attended by the curators from the History and Pacific Cultures teams. Here, curators pitch the object they want, provide the background information, and the team will have what Curator One described as a "robust discussion."

The group discussion is considered an important part of the acquisition process, Curator One stated, "Everybody has their own criteria so it's good because everybody comes with their own perspective and interrogates the object [and] the context." From this discussion, either a consensus is reached and the curator will go forward with developing their proposal, or they may be asked to provide more detail.

After the curator has gained the support of their team members, the formal acquisition process will begin. The curator will write up a detailed acquisition proposal that is then entered on to KE-Emu, the collection database used by Te Papa. There are multiple layers to the proposal, and a lot of detail is needed:

You've got to justify it, and talk about the significance, you've got to talk about its collection relationships - does it strengthen a weak area, or is it a whole new area of collecting? Does it relate to the Māori collection, for example, and if so, you've got to go to a Māori curator and get them to give you a supporting statement. You build up your case and then you describe it, photograph it, measure it. You've got to know it physically and know it intellectually. (Curator One)

${ }^{130}$ Searle, "Collecting for New Zealand," 57. 
Knowing the objects both physically and intellectually is an important way for curators to ensure they have a full understanding of what will be added to Te Papa's growing collections. ${ }^{131}$ Once completed, the proposal will then go to the Head of Department, and it will be reviewed with the team. Collection Services will then contribute to the acquisition proposal. It will be sent to Collection Management, Conservation, and Object Support who will identify any costs, freight needs, storage, or conservation work that may be required.

It will then go on to the newly formed Collection Development Committee, which is made up of the Heads for each Department, the Director of Collections Research and Learning and the Manager of Financial Accounting. By this time, Curator One stated that the proposal should be "compelling enough that it convinces the heads that the object is so important it should be in the national collection." This new step ensures that the process for acquisition is more robust than it perhaps was and enables the head to be an informed advocate on behalf of the proposed object/s. It may also mean curators may be collecting less material because of it. Should the Collection Development Committee approve the proposal, it is signed off and the deed of gift written up, or the vendor paid. Approval delegations are based on the value of the acquisition. This is a tiered process which will reach higher levels of the organisation the more the object costs. The Collection Development Committee, Chief Executive and Te Papa Board all have delegations to approve acquisitions. The object is then accessioned into the collection. External communications are handled by the curatorial teams, while the drafting of deeds, payments of invoices, and the tracking of payment and associated costs are completed by the acquisitions team. Collection Management will then organise collection and freight, and register the object. ${ }^{132}$

Due to the recent changes in policy and the Collection Development Committee system, curators are adapting their proposals to meet new requirements. This is especially so for language and how they choose to 'sell' an object in the acquisition proposal:

\footnotetext{
${ }^{131}$ June 2016 saw Te Papa withdraw a \$122,500 offer on Peter Snell's 1964 Tokyo Olympic singlet after staff determined it was a fake. That the singlet made it so far down the line of the acquisition process shows that curators may not always have the time to know an object intimately as has been suggested above. Some investigating of objects may only take place once the decision to collect an object has begun. External factors, in particular, time pressure and the use of an auction house, need to be considered. This links back to the curator's concerns about using auctions as a way to acquire objects.

${ }^{132}$ Processed confirmed by Erin McFarlane, email message to Kirstie Ross, January 24, 2017.
} 
We are going to be more strategic in our framing. We've changed our language. We're going to sell it as an object of national significance, whereas before we sold it in different terms, more in terms of historical significance, social significance, cultural significance, [and] design significance. (Curator One)

There is a mixed reaction towards this new, more robust model of acquiring objects, with curators able to identify both the benefits and the issues. Curator One stated that in the past, after the proposal was written, "from that point on [the object] would go through. There wasn't a lot of interrogation even though a lot of people would say their piece ... a bit more rigor is good." Similarly, another curator while acknowledging that the new system is "making it harder", it also means that all checks are in place. Curator Two stated, "I think they're wanting to tighten up, particularly around areas of storage ... [it's to] double check that all the arguments are really, really sound, to make sure all those checks are there."

\section{Collecting everyday material culture at Te Papa}

Having analysed how everyday material culture was and currently is collected by curators at Te Papa, this next section sheds light on some of the curators own thoughts and opinions. It provides insight into what might be seen as falling outside of the collecting processes, focussing on how curators feel and their own personal criteria, instead of what theoretically happens on paper.

\section{Curator's own criteria}

The broad nature of Te Papa's Collections Policy and Acquisitions Strategy allows for any object to be collected, so long as it can be proven to be nationally significant and meets the requirements of collection management and conservation. When asked if there were any detailed set criteria for acquiring objects, Curator Two responded, “you have criteria, but it's all in your head." The main questions curators ask when considering an object, starts simply and then delves into more detail as more is learned and the curator becomes more interested in acquiring it.

Examples of questions the curators interviewed ask themselves when deciding whether or not to collect an object include: 
- What is it?

- When was it made?

- Who made it?

- What was it for?

- What does it represent?

- Is it important itself?

- Is it representative?

- $\quad$ Is it typical?

- What condition is it in?

- What is its pathway that it took from its beginnings to its offer to Te Papa?

- Does it fit into the collection?

- Will it fill a gap the current collection?

- Will it expand or flesh out an existing area?

- Is it associated with a well-known person?

- Does it have interesting design or production history?

- Is it exhibitable?

- Does it capture stories?

It is interesting to note that none of the four curators used the words 'national', 'significance', or 'national significance' when detailing their own criteria, despite this being one of the key criteria an object is required to meet in the collection policy. Could this mean that 'national significance' is not high up on the priority list for curators at Te Papa? Or could it be that by fulfilling the other criteria listed above, an object should meet the requirement of being nationally significant by default? This may imply that curators work their way up to developing an argument for national significance once they have already made the decision that they want to collect an object.

\section{Context and the object's ability to tell stories}

The last question from the curator's criteria above, asks whether an object captures stories. This came up time and time again in the interviews. Despite the fact the term story or stories is missing from both the Collections Policy and the Strategy, ${ }^{133}$ for the curators it appeared to

${ }^{133}$ However, it is important to note the term 'narrative' is used once in the Acquisitions Strategy 2015/16. 
be one of, if not the, most important question to ask when considering an object for the collection.

Questions around the context of an object being considered for collection, and what stories it is able to tell, was of importance to all curators interviewed. The subject was raised many times when discussing acquiring everyday material culture. This is mainly due to the fact that everyday material culture tends to be the more unassuming of the material Te Papa collect:

A lot of material that we're offered is materially quite humble, but it might tell really big stories... context is really important. Sometimes it can be ugly and small but with an amazing context, sometimes it can be big and gorgeous and not have much context at all. (Curator One)

Similarly, another curator used the phrase 'chatty objects':

What you're trying to collect, I call them chatty objects. Sometimes you get an object and it's a one note, it just says one thing and ... if it says it really strongly and it's really important then maybe that's good enough. But often we're looking for objects that tell multiple stories or that you can use in multiple ways. (Curator Four)

This need for an object to tell stories mean that objects that fail to tell a story will often not make it into Te Papa's collection. An example used by Curator One was evening dresses, "There're only so many you need, unless the story is really compelling we try to reject a lot of that stuff now." While on one hand this could be seen as a positive, in terms of saving space and not doubling up on items already held by Te Papa, there is also some concern around the importance of an object telling a story. This is increased by the drive to collect only nationally significant items, and the more rigorous acquisitions process currently being developed. One example given was around the proposal put forward for a pre-World War One walking dress:

[The curator] had to really come right up and out of this one garment, come right up into business history, women's business history, manufacturing industries, New Zealand at the time. It was hugely contextualised to give it significance ... so this 
poor object which is actually super cool on its own, suddenly had to represent New Zealand's manufacturing history in a pre-World War One period. (Curator One)

The concern expressed by this curator is that objects may become overdetermined, and that the policy is requiring too much from everyday material culture.

\section{Ordinary versus extraordinary}

Each curator interviewed was asked if there was a push to collect the extraordinary over the ordinary. Overall, the consensus was that there was not an obvious push to collect extraordinary objects over the more ordinary ones, particularly when it came to social history material. It was more about what stories the object could tell than whether it had belonged to a famous person, was incredibly rare, or not. Even so, there was still some worry that in the future, some smaller objects may not be successfully collected. Using an example of preWorld War One collar supports, ${ }^{134}$ one Curator One commented that although minor, "it's a really interesting history about the feminine body." However, recent changing in the collection process, with the addition of a new level of clearance in the form of the Collection Development Committee. Curator One, expressed some concern: "I'm just a bit scared now ... they'd get through our level; we all love them ... but I don't know if [the Collection Development Committee] level will get it. They'd probably say 'don't waste our time, get rid of them, get them back to the second-hand market." While on one hand this could be seen as a valid concern, on the other, it may express a certain apprehension about change. This could simply be a period of adjustment for curators, moving from being able to collect anything they see fit to a process that perhaps has different priorities, that will require curators to fight for an objects place in Te Papa's permanent collection.

Another curator commented on competing ideas as to what a museum should be collecting. Curators have to negotiate people's preconceived notions around what a museum is, and what it holds in its collection.

A museum is known for its collection. If a museum has an outstanding collection, it tends to get good visitation, it attracts good staff. If you've got what is considered a

\footnotetext{
${ }^{134}$ Small metal objects that women would use to keep high collars stiff.
} 
mediocre collection which has been inappropriately curated, a museum's credibility gets a bit waver-y. (Curator Two)

This comment suggests that poor curating, perhaps due to unfocussed collecting, has led to the belief that everyday material culture can make for a mediocre collection. However, the value of an object can change considerably over time, so that something which was once considered a throw away object, can become precious. Curator Four responded by saying that the ordinary can be extraordinary, it's about the stories the object can tell.

The quote below, taken from Curator One's interview, demonstrates some of the issues everyday material culture objects create:

I was taught to treat all objects in the same way, that they all have value and [should] be kept equally. And I've been told ever since that that's rubbish... that's possibly why I do like collecting the everyday, because I don't see why that can't be as precious as that because they're both significant in their own right.

During the interviews with curators, it became apparent that there is tension about what is viewed as significant when it comes to collecting everyday material culture. The concern for the curators here is that there may be a different interpretation of "nationally significant" between curators and the senior leadership team who contribute to collection policy documents.

There is also room for different interpretations for terms used in Te Papa's collecting documents. Curators are concerned that they do not have a strong grasp on what kind of material they are expected to collect:

Do you identify the gaps and then fill them? Or do you sort of constrain that type of collecting, the everyday social history, and do you go for the iconic? ... Word from above is to collect more iconically, but the jury's out on what's iconic... [The Board] want to see immediate, iconic material on the table and I don't know what they're thinking. (Curator One) 
Aesthetics also plays a large part in how people view objects. As has been discussed in Chapter Two, there is a concern that objects which are "materially quite humble" will now struggle to be accepted by the new level of clearance an acquisition proposal must go through:

Sometimes the very ordinary-ness and the very weak materials, the material that things are made from, really work against them. People will dismiss them very quickly, if they're not good looking enough, they can really struggle. Aesthetics do play a big part, we joke about it, but they do play a big part. We talk about history being ugly, that we have to get over it because a lot of it is pretty ugly. So that's probably part of our problem with the higher up levels... they look at it and go, 'what do you want that old dudder for?' (Curator One)

There is an ongoing tension between the curators and their perceptions of what the executives and Board deem worthy of collection. While the curators believe that senior management may want objects that are immediately impressive, in terms of who they belonged to, or how they look, the curators are much more concerned with the story that comes along with the object:

The History team in particular... have collected ephemera from across time. Protest materials, t-shirts, uniforms, small things. Things that some critics of Te Papa have kind of mocked Te Papa for... but what you're doing when you're collecting that material, it's not actually the value of the t-shirt or badge, it's the value of the story that comes with it. If you want to tell the story of a protest movement that may have only existed for a couple of years and all that's left of it is a badge and a t-shirt, of course that's your most important thing to collect. Otherwise, the only way to tell it on the exhibition floor would be through graphical panels, or reconstruction of some sort. Nothing eclipses that quality of engaging with the physical, or engaging with an objects. It kind of makes history more tangible. (Curator Two)

Here, you can see that the curator understands that the object is important not because of what it materially is, but because of what it means, and the story the curator can form from it. While museums have been moving away from displaying only the great and wonderful, as 
many attempt to move from temple to forum, ${ }^{135}$ the interviews revealed however, that curators are very aware that there is still a hierarchy that exists in Te Papa's collections. The everyday objects they bring in to the collection have a tendency not to be taken as seriously as other material objects might. Curator Four stated, "I've heard other collection managers refer to the history collection as 'bric-a-brac'... [there's] perceptions that it's not glamourous, or that old fashioned idea that museums are still for the high end." Having to prove the significance of an object however, is not necessarily a bad thing. Curators must put forward their case in order for an object to earn its place within Te Papa's collection. If there is a hierarchy that exists in Te Papa's collections, then these proposals should help to soften it:

It's the whole thing around the notion that there is high art and low art, and I am ferreting away in low art. It's not until I articulate my argument, and advance my argument, that people chill out... it's high art/low art bullshit, it's the argument and the story that counts. (Curator Two)

Tensions between what is perceived as art/craft and what is not has been explored before. ${ }^{136}$ Everyday objects in particular struggle to be treated as something which holds great merit. The interviews revealed a frustration among curators because of this point. However, these notions of high art and low art, and the elite and the ordinary, show how the curators could use everyday material culture to present history 'from below'. These objects are usually not associated with an elite way of life, and therefore allow the curators to tell the story of who they consider to be "everyday New Zealanders" - something which is highlighted in the Strategy. ${ }^{137}$

\section{Summary}

The acquisitions process at Te Papa has become increasing complex, as the museum strives for more focussed and purposeful collecting. Everyday material culture most often arrives into the collection via donation, throwing up issues around reactive, ad-hoc collecting when the curators' preferred method is proactive. Both reactive and proactive collecting is limiting.

\footnotetext{
${ }^{135}$ See Conn, Do Museums Still Need Objects? 2010.

${ }^{136}$ Blyss Wagstaff, "Jewellery as art and/or craft: an investigation of contemporary jewellery collections and collecting in New Zealand museum," Master's thesis, Victoria University of Wellington, 2008.

137 Acquisition Strategy 2015-16.
} 
Te Papa needs to find a balance between the two so they can effectively collect what they plan, and make room for the pleasant surprises.

The acquisition process, designed to vet any objects that may not be beneficial to Te Papa's collections changed focus with new changes made in 2016. These changes mean that fewer objects may be collected in the future, ensuring that every single item that enters Te Papa fulfils the requirement of being nationally significant.

The importance of collecting 'chatty objects' - objects that successfully tell a story - was brought up time and time again in the curator interviews. What the object is and how it looks therefore becomes secondary to the story that the object represents. This means that the distinction for what may be considered ordinary and extraordinary is blurred. The acquisition proposals showed how this argument is built by the curators, and their ability to link objects to its wider context. These proposals did show however, that the story was only one part of the acquisition proposal, and that other criteria such as exhibition potential, and collection relationships still needed to be met and justified.

The interviews revealed a perceived tension between curators and senior management especially in light of the development of a more layered approval process. ${ }^{138}$ Curators are worried that objects they think deserve to be collected may now be rejected. As this research lacks the voices of senior management, it is hard to draw conclusions as to whether these concerns are founded. However, in the next chapter, I argue that this tension may actually be a somewhat inevitable tension between policy and practice, with the senior management team coming to represent policy, and the curators representing practice.

\footnotetext{
${ }^{138}$ Senior management were not interviewed as part of this research, the perceived tension is a result of the curator interviews only.
} 


\section{Chapter Three: \\ Policy versus practice}

Having reviewed how Te Papa collects on paper versus in practice in the earlier chapters, this next chapter examines the implications of the revealed tensions. The chapter begins with an examination of some of the issues with collecting everyday material culture as highlighted in the previous chapter. This includes how everyday material culture may struggle to be taken seriously, the huge amounts of it that exist, and the trouble with contemporary collecting and the inability to collect it without the use of hindsight. Next is a discussion of the tension that exists between policy and practice and the implications. Lastly the chapter concludes with an attempt to provide a revised definition of the term everyday material culture.

\section{The problem with everyday material culture}

The curator interviews revealed a number of issues museums encounter when collecting everyday material culture. Te Papa currently faces issues that most, if not all, museums around the world are grappling with. Budget and staff cuts, lack of resources and time, and an ever decreasing amount of space mean that museums are needing to carefully plan their future and plot out their purpose. While museum theory on the future of collecting pushes the need to develop clear strategies for collecting, once in play, these policies, strategies, and plans come up against real, on the ground issues and attitudes that have been developed over decades.

Everyday material culture brings its own set of challenges to museums and the development of collecting plans. While curators know the value that this material can bring to a museum, what issues are there in collecting it? And how are these to be mitigated?

\section{- 'The sheer amount of it'}

A major issue with bringing new material into the collection is storage space and resources. This does not only fall on everyday material culture, but every object being considered for acquisition. Curator Three commented, "We have a terrible problem with lack of storage space and resourcing collection care, which shouldn't really drive collecting but to some extent it does." Curator One also expressed this concern, "As time goes by and the Board get 
nervous about storage and the cost of storage, and the fact we're running out, people start to interrogate why you're collecting 'that pen', do you really need it?" The concern for space is a very real one, and objects being proposed for collection should be interrogated.

As I pointed out at the start of my introduction, one of the major issues with everyday material culture, that perhaps separates it from other types of material culture, is what Curator Four called the "sheer amount of it." Were, as we have seen, argues that museums need to adopt a more strategic approach to collecting in the future in order to ensure museums do not become "unmanageable time capsules" filled with "collections of the everyday," but how exactly a museum may do that still remains unknown. ${ }^{139}$ Is the everyday worth remembering? Museum curators, including those at Te Papa need to make difficult decisions about what objects are selected to be preserved for future generations, and which are left behind to be forgotten.

Te Papa's new, tighter restrictions on what can and cannot be brought into the collection is an attempt to gain control over its potentially "unmanageable" collection. For many museums, including Te Papa, re-prioritisation within strategies, policies, and plans has become very important. The focussed nature of the proposed Collection Strategy discussed in the first chapter is a strong attempt by Te Papa to "collect strategically." ${ }^{140}$ The problem of storage is directly addressed in this, with four of the five collecting areas identifying "storage is at near capacity in all areas" as a direct threat to Te Papa's collections. ${ }^{141}$

\section{- Gaps in collections}

Previous collecting regimes, past conceptions of history, and the relatively recent advent of history in the national museum has led to gaps in Te Papa's collections. ${ }^{142}$ The amount of everyday material culture, the ephemeral nature of it, and the prioritising of iconic items could perhaps lead to gaps in the future.

Current gaps in collections could be explained by curators prioritising some objects over others. In the past, museums aimed to be a 'temple on the hill', places where the public could

\footnotetext{
${ }^{139}$ Were, "Extreme Collecting", 10.

${ }^{140}$ Collection Strategy 2016-2021.

141 Ibid.

${ }^{142}$ See comments in: Ross, "Materialising Social History in Museums"; and Collection Strategy 2016-2021.
} 
come and be educated and become more informed citizens. It could simply be that the curators at that time did not see everyday material culture as a part of their collections, items to be used to educate the masses. Priorities change, and objects can change in value. These gaps could have formed because curators failed to predict what objects would be considered significant in the future. Similarly, ideas about history and history collecting have changed overtime; social history is now the prevailing paradigm at Te Papa, but this is relatively recent considering Te Papa's collections has its roots in the 1865 Colonial Museum. With its emphasis on 'history from below', the lives of 'ordinary' people have only come to the fore since the 1980 s.

Yet, the opinions of the curators who I interviewed in this study suggested that the representation of everyday material culture within the collection was "pretty good." This is not to say that gaps do not exist. Labrum's Real Modern is an example of gaps in Te Papa's collection, with only around 50\% of objects featured in it sourced from Te Papa. Unsurprisingly, some areas in the museum were considered more complete, or representative than others. A major gap identified during the interviews was around the diverse groups of people living in New Zealand. Curator One noted, "We have a really strong social history collection around Pakeha history, but very little on many, many of the diverse groups that are here.” This is true also of the Mātauranga Māori collection in terms of representing the everyday material culture of Māori post-nineteenth century. This is discussed later in the chapter.

While identifying and filling gaps in the collection is often a priority for Te Papa, ${ }^{143}$ this can also be problematic. "The more and more we produce," argues Curator Four, "the more and more possibilities there are to collect." This links back into the earlier problem of how museums decide what to collect when there is so much of it to choose from. Policy, strategy and plans all work to help curators focus on specific collecting priorities.

\section{- Collecting retrospectively}

The question about what objects may be considered significant to future generations is one that curators grapple with every day. Another issue with museum collecting is time and the ephemeral nature of some types of everyday material culture. Yet Gardner highlights that

${ }^{143}$ This is explicitly stated in the History section of the Acquisitions Plan 2015-16. 
many curators would argue it is best to collect after a certain period of time has passed. ${ }^{144}$ Curator One commented on the nervousness of senior leadership around contemporary collecting, 'I just feel, if we don't collect stuff as it impacts, it's really hard to do it retrospectively... [My boss is] worried about the significance because you haven't got hindsight. A lot of it is just too late, it just goes, it's so ephemeral." Similarly, another curator mentioned a 'danger period' for objects of about twenty years, where an object is not seen as old and obsolete, but not yet precious enough to keep. A problem has developed where the museum is unsure about collecting contemporary material for fear of it losing its significance, but may equally lose out on collecting a significant item because of this nervousness. By waiting, Gardner argues, museums could be missing out of collecting opportunities in today's "increasingly disposable world.",

One curator offered up the suggestion of "stockpiling" objects, saying they like the idea of being able to collect as much as they liked individually, put it away, and return to it after a period of time to see what should actually make it into the permanent collection. Knell's theory of allowing objects to "flow in and out" could be implemented here, so that museums no longer become a place for redundant things. ${ }^{146}$ This could potentially provide museums with some flexibility, and afford staff confidence when making decisions about collecting the contemporary.

\section{- Collecting stories}

The idea of collecting stories was raised by the curators time and time again. Pearce argues that the way to collect contemporary mass-produced objects is to focus on the link between the material object and the lived life; in this way a museum collection is able to become a way to "travel through experience." 147 Through the interviews, it became clear that curators see the value in everyday objects through the stories they are able to tell. By collecting "chatty objects," the curators are ensuring that the objects which enter Te Papa's collection are able to tell a story, whether it is a personal story, a story about the time or place, or ideally, both. The question here is who decides whose story is worth telling?

\footnotetext{
${ }^{144}$ Gardner, "From Idiosyncratic to Integrated," 215.

145 Ibid.

${ }^{146}$ Knell, Museums in the Material World, 17.

${ }^{147}$ Pearce, "Knowing the new," 100.
} 
The emphasis on story as a way to determine the relative value of an everyday object has some issues. If an object is already held by the museum but there is no story associated with it, and then that same object gets offered as a donation but also comes with an interesting story, does that mean it should be collected too? What about two identical objects that have two very different, but equally important stories? What would happen there? Which object would make it to the storeroom? These are not necessarily questions that need answering, but they do lead to an additional question: Is the story more important than the object itself? One could certainly argue that the object is the story, and that you cannot separate them out.

There are other factors to take into consideration. If you are collecting a story alongside an object, you could be collecting a number of further objects to complete the story. For example, the story of a wedding dress could be made more complete with a photograph of it being worn on the bride's wedding day. This means that in deciding to collect an object, you could also collect a number of supporting stories alongside it. Another example of this could be the Mac Plus computer guide for Chapter Two's case studies. One of the arguments put forward by the curator was that it belonged alongside a computer already held in the collection. Furthermore, because both items came from the same donor, collecting the guide not only completed the physical object, but also helped to complete the story.

\section{- For Māori}

In deciding what stories to collect, museums are also deciding whose stories to tell. The value of everyday material culture being collected and displayed by museums is of special concern to groups other than Pakeha, who often find themselves underrepresented, or perhaps misrepresented, in museums. When asked if there were benefits to collecting everyday material culture, the Curator Māori stated:

For my people, it's especially important [to collect this type of material] because museums don't really take notice of Māori, unless it's our early history... My concern is that historical representation of Māori should show that we are continuing to thrive and adapt and innovate and a lot of that you will see through high culture kind of material, but also through the everyday material that shows the gradual incremental steps towards something... I consider my collecting not just for the Māori collection but to also try and colonise the History collection, so that the History collections... will feature [Māori] as well... That's why the everyday objects are really important, 
especially for Māori, because we tend to only be represented in museums through our great leaders, our weapons... our cloaks, but that's not our reality, that's our history. (Curator Two)

Through the lack of contemporary social history objects, and objects of everyday material culture, museums fail to represent communities that have adapted to a colonial and postcolonial world. As Curator Two put it, "We didn't exist after the settlers." Pacific Cultures curator Sean Mallon writes about the shock visitors experience when shown a palau (Niuean drum) created from the British Paints paint tin, which is in Te Papa's Pacific Cultures collection. ${ }^{148}$ Mallon argues however, that this drum is far from "ordinary", not only because it is a significant element in Niuean cultural performance, but also because it successfully represents a different cross-section of society outside of the cultural elites. ${ }^{149}$

Contemporary social history collecting is still a developing discipline within indigenous museology. Matariki Williams' research into how contemporary Māori society is collected at Te Papa sheds some light on the subject. She calls for the application of the guiding principle of Mana Taonga ${ }^{150}$ to Te Papa's collecting practices arguing that it not only acknowledges the importance of the object itself, but also of the community it was collected from. ${ }^{151}$ Through this, "Te Papa has the potential to achieve a national museum that truly speaks for the nation, that has tendrils out into these various source communities whom it honours through the acknowledgment of their own authority." 152

\section{- Collaborative collecting}

While there has been criticism towards democratised collecting, in their interviews three of four curators mentioned that pro-active, collaborative collecting was their preferred method of collecting. ${ }^{153}$ In the past at Te Papa, it has usually been the curator selecting the objects, and deciding how these objects are interpreted in exhibitions. Through collaborative

\footnotetext{
${ }^{148}$ Mallon, “Against Tradition,” 370.

${ }^{149}$ Mallon, "Against Tradition," 371.

${ }^{150}$ Definition of this philosophy is described by Williams as an acknowledgement of: "the spiritual and cultural connection of all communities to the taonga (treasures) and other collection items held by Te Papa. For more on this subject, see Williams, "Ka hao te rangatahi", 2014.

${ }^{151}$ Williams, "Ka hao te rangatahi", 63.

152 Ibid.

${ }^{153}$ For further criticism of collaborative collecting in museums see: Bernadette Lynch, Whose cake is it anyway? A Collaborative Investigation into Engagement and Participation in 12 UK Museums and Galleries, (London: Paul Hamlyn Foundation, 2011).
} 
collecting, the museum works with the communities they wish to collect from. Potentially, agency is handed back to communities which enables them to figure out how they want to be remembered. Curator Four described this type of collecting as a negotiation, where the curator does the research and approaches the group or individual to have a conversation about what that group would deem appropriate for Te Papa to collect. Ultimately, the curator would not give up total agency, and the museum would have final say over what is collected, but the group has been given the opportunity to voice their opinions and have some input into how they are represented. ${ }^{154}$

However, Mallon argues that it is essential that curators maintain authority over collecting and collection building. ${ }^{155}$ Still, one of the curators provocatively posed the question that if you went back in time to a pre-European village and asked the Māori who live there to give Te Papa 27,000 objects that tell the story of how they are living, would those 27,000 objects be the same as those currently held in Te Papa's Mātauranga Māori collections today? While there is no right answer to this question, the curator believes that the material collected would look vastly different, with more of an emphasis on domestic objects, things to help prepare food and things that were for play, as well as the more familiar objects we see in museum collections. However, historically Māori did contribute to what museums collected and did not necessarily want it to be everyday material culture. At the time, it was more likely that Māori would want their rare and beautiful taonga going into the hallowed halls of their national museum. ${ }^{156}$ How exactly, and whether, collaborative collecting would accommodate everyday material culture is difficult to predict. However, should groups be consulted about what to collect, it would not be surprising that they should want exceptional examples to be representing them in a national museum, and not the everyday.

\footnotetext{
${ }^{154}$ See Searle, "Collecting for New Zealand" for more on this.

${ }^{155}$ Mallon, "Against Tradition."

${ }^{156}$ See: Rodney Harrison, Sarah Byrne and Anne Clark (eds.), Reassembling the Collection: Ethnographic museums and indigenous agency, (Santa Fe: School for Advanced Research Press, 2013);

Conal McCarhty, "To Foster and Encourage the Study and Practice of Maori Arts and Crafts: Indigenous Material Culture, Colonial Culture and Museums in New Zealand." In Craft \& Community: The Material Culture of Place \& Politics, 19th-20th Century, edited by Janice Helland, Beverly Lemire and Alena Buis, (Aldershot: Ashgate, 2014): 59-82.
} 


\section{Tensions between policy and practice}

As seen above, many of the issues that come with collecting everyday material culture can be mitigated through policy, strategy and careful planning. This section explores the tension that exists between policy and practice at Te Papa. While collecting policies lay the groundwork for museum's collecting practices, both Knell and Gardner argue that more detailed collection plans and strategies are needed to further rationalise collecting. As identified by Gardner, planning can:

- Allow a museum to gain intellectual control over its museum at an operational level;

- Allow a museum to better utilise shrinking resources (budgets, staff, space);

- Enable a museum to determine what they are not doing. ${ }^{157}$

The reality for museums now is that they no longer have the resources to collect everything that might interest them, and Gardner argues that plans are needed to "collect better and smarter, and to make difficult decisions." 158 Planning, as opposed to policy, "focusses on the ideas, concepts, stories or themes that provide the rationale for the museum's collecting decisions." $" 159$

Resistance to collection planning is taken into account by Gardner, and it is possible to see something of this kind of phenomenon in this research. Knell argues museum collecting should not rely on individual staff members but instead needs to be rationalised within its institutional context. ${ }^{160}$ This planning challenges curatorial authority by developing a museum-wide vision instead of an independent curatorial one. ${ }^{161}$ The interviews gave the impression that in the past curators were, to some extent, essentially able to collect what they wanted. Te Papa has over time, and recently, been changing their policy and strategy to discourage this. Curators expressed their concern over a tightening of policy, but also acknowledged that a more robust process was probably needed. It is highly possible that with the recent changes, curators at Te Papa are feeling constrained, no longer able to collect their own vision but instead having to fit into one that has been written for them. The resistance

\footnotetext{
${ }^{157}$ Gardner, "From Idiosyncratic to Integrated," 206-207.

${ }^{158}$ Gardner, "From Idiosyncratic to Integrated," 207.

159 Ibid.

${ }^{160}$ Knell, “Altered Values," 15-19.

${ }^{161}$ Gardner, "From Idiosyncratic to Integrated," 216.
} 
here does not seem to be towards the annual collection plans, which have been in place for some time at Te Papa, and to which the curators directly contribute. Rather, the curatorial concern is over the refocussed collection strategy and new approval processes currently being put in place.

Policy and planning, if done well, can be useful tools for curators trying to make sense of everyday material culture. While the tension between policy and practice exists when collecting any type of object, it seems to be heightened when it comes to collecting everyday material culture. I argue that this is because a divide exists between what is seen to make a good national collection, and what is not. The Te Papa curators perhaps feel defensive when it comes to objects that seem 'ordinary' or 'mundane' because they feel they will not be taken seriously by senior management, who are perceived to be unreceptive to these types of objects. Policy exists so that if an object proves to be nationally significant, and can be stored and preserved, it will be collected. In practice, however, this may not be the case. Planning works to mitigate against individual visions from collecting; however, curators will still have opinions and so will those who make the final decisions. As long as there is human intervention in collecting, individuals will continue to shape collections subjectively. While planning and policy cannot remove the individual completely, they can focus the vision of the museum, aligning the rationale of collecting with institutional priorities. ${ }^{162}$

\section{Defining everyday material culture: "Whose everyday?"}

Early on in my research it became clear that there was no one definition for everyday material culture. The term 'everyday' opens itself up to a myriad of interpretations and as a result, this definitional fluidity means that collecting the everyday can be challenging for curators. When the now superseded 2015/16 Acquisitions Strategy stated that Te Papa would collect "items that reflect aspects of everyday life in New Zealand" what did that actually mean? No clear definition of the term 'everyday' opens it up to a much wider interpretation. The final section of this chapter provides some clarification.

${ }^{162}$ Gardner, "From Idiosyncratic to Integrated," 206. 


\section{- Working definition of everyday material culture}

The literature review examined working definitions of material culture by both Schlereth and Smith. These are used to build a definition for the term everyday material culture. Designed with a museum context in mind, Smith sought to define material culture as discrete items which can be lifted up and moved somewhere else. ${ }^{163}$ With this in mind, we now need a definition of exactly what everyday may mean. The dictionary definition of 'everyday' describes the word as meaning something which is encountered or used routinely or typically. However, much like material culture, the term everyday is also often used interchangeably with other terms such as 'ordinary,' and 'commonplace.'

In order to help develop my own definition of everyday material culture, I first asked each of the curators interviewed to provide me with their own:

"I like to think of it as an object that is familiar, and it's with you, and it's useful and helpful, and every so often it does a wee twist on you, it becomes really provocative." (Curator One)

"Things that help you live your life on a day-to-day basis. Things that help you eat, help you make your kai, things that dress you, things that convey you somewhere ... Stuff that for me isn't associated with an elite way of life." (Curator Two)

"Objects that people used in their daily lives." (Curator Three)

"For me, it's the everyday stuff of life." (Curator Four)

The curator's definitions above, while similar, are not uniform. This means that their understanding of what is 'everyday' differs from each other which could result in inconsistencies when it comes to collecting. When asked to provide their own definition of everyday material culture, one curator stated, "it's hard, because whose everyday?"164 Some of the everyday material culture for a millionaire might differ greatly from the that of a public servant. It is also difficult in terms of everyday material culture and uniqueness. For this

${ }^{163}$ Smith, "City revealed," 18.

164 Ibid. 
research, the term can refer to both items which are mass-produced, like a toothbrush or a plastic supermarket bag, and items which are one off, such as a homemade wooden skateboard. These could both be considered everyday items despite the fact that in terms of their uniqueness they differ dramatically.

My original definition for everyday material culture included the line, "not associated with an elite way of life" as provided by Curator Two. However, after some reflection, I decided to remove this. An elite way of life is, for some, their everyday. It therefore deserves to be included in the definition. For the purposes of this research, and as a guide for curatorial practice, I suggest the following working definition of everyday material culture, using ideas put forward by the curators. I define everyday material culture as, 'items that exist in the material world which have been created by or used by humans in order to help live their lives on a day-to-day basis.' This definition encompasses both the unique, handmade and the massproduced and can be both man-made or natural. The everyday can also be iconic, the two cannot be separated. A glass milk bottle used for school milk in the 1930s is an example of everyday material culture that is iconic and nationally significant as well as mass-produced. It is my hope that this definition may provide some clarity for museum professionals in understanding what objects may be labelled as everyday material culture.

\section{Summary}

Using Knell and Gardner's arguments for the importance of collection planning, and the information gathered from interviewing and observing the curators, this final chapter views policy, strategy and planning at work in a real museum. The chapter highlights some of the issues the curators at Te Papa experience when approaching the challenge of collecting everyday material culture. Practical issues presented by everyday material culture, such as its sheer profusion and the struggle for it to be taken seriously, mean that curators feel everyday material culture is at the risk of being rejected for collection. Tensions exist between policy and practice, and Te Papa's newly refocussed policy and strategy documents are making this divide more visible. However, I argue that the policy, strategy, and plans in place at Te Papa should be used by curators as a way to make sense of everyday material culture in order to help them mitigate the issues it throws up. 
A recurring issue in this research was the difficulty of defining what is and is not 'everyday.' In order to provide some clarity, this chapter concluded with a definition of everyday material culture. The nature of the everyday means that it will always carry a multiplicity of meanings for many people. However, the definition may give curators a starting point for understanding what everyday material culture may, or may not, be. 


\section{Conclusion}

This dissertation has examined how Te Papa collects everyday material culture, and the decision making that surrounds it. In particular, it examines the issues around collecting everyday material culture, and how collection planning may be used as a useful tool for curators attempting to collect it. It provides an in-depth view of Te Papa's current collecting processes, from how Te Papa collect on paper, to how they collect in reality. It addresses gaps in literature on institutional collecting, particularly in a national museum setting. By observing and interviewing curators, I was able to respond to Gardner's call for research that approaches collecting from an internal 'on-the-ground' viewpoint.

My research shows that curators are concerned more with the building of stories, than with an object alone. In this way, everyday material culture has the ability to be significant, provided it can be proven to be so. Having existed in ethnological collections, the practice of collecting objects as an aspect of social history is a relatively recent phenomenon. As a result, everyday material culture can be problematic when considered alongside traditional museum collecting. The curators interviewed felt that at times they struggle to get everyday material culture taken seriously, with one curator saying that it may not be seen by the public to make a 'good' collection. Policy would, however, have us believe that this should no longer be the case, and provided an object's national significance can be proven, it should be collected.

It was challenging that this research took place at a time of change for Te Papa. New processes and documents meant that curators still did not have a complete understanding of how collecting would be undertaken in the upcoming years. On the other hand, these changes had perhaps forced the curators into a state of reflection and contemplation at the time I was interviewing. The fears (although as yet unfounded) brought up by curators, namely about the prospect of objects they consider to be important being rejected because of the new policy were revealing. A tension clearly therefore exists between policy and practice at Te Papa, although this has manifested itself in what seems more like a perceived tension between curators and senior management. The curators interviewed seem to feel they are becoming more restricted by 'upper levels', however it is not necessarily up to senior management to reject an object, but is instead a case of whether the object fulfils the criteria set out in the policy. 
At Te Papa, everyday material culture exists at a crossroads of two conceptions of collecting. Policy enables its collection provided it demonstrates national significance. However, curators are less concerned with this aspect of an object. This discrepancy occurs because of the challenging nature of everyday material culture, namely its mutability; it can be all things to many people. What this dissertation shows is that policy does not always trump practice unless strict approval processes are put in place.

This investigation into how Te Papa collects everyday material culture highlighted other areas of research that this dissertation was only able to touch on. Further research into the profusion of everyday material culture could be undertaken, in order to better understand how museums may tackle this problem. This could also bring in deaccessioning, so that museums are no longer collecting in perpetuity, but instead collecting with the freedom of being able to let go of objects that are no longer of importance, or in scope. Lastly, deeper research into how policy works on the ground is needed. Museums are continuing to tighten, refine and refocus their collecting documents. A comprehensive understanding of how these documents work at ground level is needed.

In closing, this research aimed to provide insight into how and why Te Papa collects everyday material culture. Although tension exists between policy and practice, it has revealed how careful planning through policies, strategies, and plans, can work to grow meaningful collections. Collection planning is an absolute necessity for museums. With cuts to resources and space now at a premium, it is important that museums figure out their purpose and begin to collect more strategically. While this can be restrictive for curators, it also means that objects which now make it into Te Papa's collection are there because they fit entirely with their overall institutional vision. What is needed is for Te Papa to find a balance between careful planning, while also allowing space for unexpected collecting opportunities. Everyday material culture deserves a place in New Zealand's national museum collection. It has the ability to teach us about the way we live, and can help identify our place in the world. Through careful planning, Te Papa is working to build a strong collection for future generations, where every object has earned its title of 'nationally significant' and where the ordinary can be extraordinary. 


\section{Bibliography}

\section{Books and articles}

Attwood, Bain. "Difficult Histories: The Museum of New Zealand Te Papa Tongarewa and the Treaty of Waitangi." The Public Historian, 35, no. 3 (2013): 46-71.

Brosnahan, Sean G. To Fame Undying: The Otago Settlers Association and its museum, 1898-1998. Dunedin: The Association, 1998.

Conn, Steven. Do Museums Still Need Objects? Philadelphia: University of Pennsylvania Press, 2010.

Dudley, Sandra H. "Encountering a Chinese Horse: engaging with the thingness of things." In Museum Objects: Experiences the Properties of Things, edited by Sandra H. Dudley, 1-16. Oxon: Routledge, 2012.

Gardner, James B. "From Idiosyncratic to Integrated: Strategic Planning for Collections." In The International Handbooks of Museum Studies: Museum Practice, edited by Conal McCarthy, 203-220. John Wiley \& Sons, Ltd: 2015.

- "Preserving/Shaping/Creating: Museums and Public Memory in a Time of Loss." In The International Handbooks of Museum Studies: Museum Theory, edited by Andrea Witcomb and Kylie Message, 511-530. John Wiley \& Sons, Ltd: 2015.

Harrison, Rodney, Sarah Byrne and Anne Clark (eds.). Reassembling the Collection: Ethnographic museums and indigenous agency. Santa Fe: School for Advanced Research Press, 2013.

Harvey, Karen (ed.). History and Material Culture: A student's guide to approaching alternative sources. Oxon: Routledge, 2009.

Hunter, Kate and Kirstie Ross. Holding on to Home: New Zealand stories and objects of the First World War. Wellington: Te Papa Press, 2014.

Knell, Simon J. "Altered values: searching for a new collecting." In Museums and the Future of Collecting (Second Edition), edited by Simon J Knell, 1-46. Aldershot: Ashgate Publishing Limited, 2004.

. (ed). Museums in the Material World. Oxon: Routledge, 2007.

Labrum, Bronwyn. "Dressing History Up: Introduction." In Looking Flash: Clothing in Aotearoa New Zealand, edited by Bronwyn Labrum, Fiona McKergow and Stephanie Gibson, 1-11. Auckland: Auckland University Press, 2007.

"Material Histories in Australia and New Zealand: Interweaving distinct material and social domains." History Compass 8, no. 8 (2010): 805-816. 
Real Modern: Everyday New Zealand in the 1950s and 1960s. Wellington: Te Papa Press, 2015.

Livingstone, Rosanne. "The History and Development of Foreign Ethnology Collections in Museum of New Zealand Te Papa Tongarewa. Tuhinga 10 (1998): 1-29.

Lynch, Bernadette. Whose cake is it anyway? A Collaborative Investigation into Engagement and Participation in 12 UK Museums and Galleries. London: Paul Hamlyn Foundation, 2011.

Mallon, Sean. “Against Tradition.” The Contemporary Pacific 22, no. 2 (2010): 362-381.

McCarthy, Conal. "To Foster and Encourage the Study and Practice of Maori Arts and Crafts: Indigenous Material Culture, Colonial Culture and Museums in New Zealand." In Craft \& Community: The Material Culture of Place \& Politics, 19th-20th Century, edited by Janice Helland, Beverly Lemire and Alena Buis, 59-82. Aldershot: Ashgate, 2014.

McCarthy, Conal and Jonathan Mane-Wheoki, "Afterword: the Wharenui Mataatua, and some thoughts about things." In The Lives of Colonial Objects, edited by Annabel Cooper, Lachy Paterson and Angela Wanhalla, 311-320. Dunedin: Otago University Press, 2015.

McCredie, Athol. "Collection photographs: The development of Te Papa's historical photography collection.” Tuhinga 20 (2009): 41-66.

Macdonald, Charlotte. "Two peoples, one museum: Biculturalism and visitor 'experience' at Te Papa Our Place, New Zealand's new national museum." In Contested histories in public space: Memory, race, and nation, edited by D. J. Walkowitz \& L. M. Knauer, pp. 49-70. Durham and London: Duke University Press, 2009.

McDonald, Sharon. "Collecting Practices." In A Companion to Museum Studies, edited by Sharon McDonald, 81-97. Oxford: Blackwell Publishing Ltd, 2006.

Merriman, Nick. "The Future of Collecting in "Disciplinary" Museums: Interpretive, Thematic, Relational." In The International Handbooks of Museum Studies: Museum Practice, edited by Conal McCarthy, 249-265. John Wiley \& Sons, Ltd: 2015.

Miller, Daniel. Material Culture and Mass Consumption. Oxford: Basil Blackwell, 1987. Stuff. Cambridge: Polity Press, 2010.

Pearce, Susan. "Knowing the new." In Extreme Collecting: Challenging practices for 21 st century museums, edited by Graeme Were and J.C.H. King, 93-101. New York: Berghahn Books, 2012.

. (ed). Museum Studies in Material Culture. Leicester: Leicester University Press, 1989. 
Reillo, Giorgio. "Things that shape history: material culture and historical narratives." In History and Material Culture: A student's guide to approaching alternative sources, edited by Karen Harvey, 24-46. Oxon: Routledge, 2009.

Ross, Kirstie. "Materialising Social History in Museums." Te Ara Journal of Museums Aotearoa 32, no. 1-2 (2007): 1-5. Accessed March 12, 2016, http://www.museumsaotearoa.org.nz/sites/default/files/te ara/3212krmalow.pdf

Schlereth, Thomas J. Material Culture: A research guide. Lawrence: University Press of Kansas, 1985.

Stavenow-Hidemark, Elizabet. "Home thoughts from abroad: an evaluation of the SAMDOK Homes Pool.” In Museums in the Material World, edited by Simon J. Knell, 51-59. Oxon: Routledge, 2007.

Thomson, Keith W. Art Galleries and Museums in New Zealand. Sydney: Reed, 1981.

Were, Graeme. "Extreme Collecting: Dealing with difficult objects." In Extreme Collecting: Challenging practices for 21st century museums, edited by Graeme Were and J.C.H. King, 1-18. New York: Berghahn Books, 2012.

Woodward, Ian. Understanding Material Culture. London: SAGE Publications Ltd, 2009.

Young, Linda. "Significance, connoisseurship and facilitation: New techniques for assessing acquisitions." Museum Management and Curatorship 13, no. 2 (1994): 191-199.

. "Collecting: reclaiming the art, systematising the technique." In Museums and the Future of Collecting (Second Edition), edited by Simon J Knell, 185-195. Aldershot: Ashgate Publishing Limited, 2004.

\section{Interviews}

All recordings held by Amy Hackett

Curator One, Wellington, 22 September 2016

Curator Two, Wellington, 30 September 2016

Curator Three, Wellington, 11 October 2016

Curator Four, Wellington, 17 October 2016

\section{Museum of New Zealand Te Papa Tongarewa documents}

Acquisitions Plan 2015-16

Acquisitions Strategy 2010/11

Akeli, Safua. "Acquisition Proposal 3072 - Collection of tivaevae, cushion covers, and tivaevae-making ephemera." Museum of New Zealand Te Papa Tongarewa, September 26, 2008. 
Collections Policy 2016

Draft Acquisitions Strategy 2015/16

Gibson, Stephanie. “Acquisition Proposal 2851 - Andrea Hill collection.” Museum of New Zealand Te Papa Tongarewa, February 29, 2008.

Gibson, Stephanie. “Acquisition Proposal 2852 - Andrea Hill collection.” Museum of New Zealand Te Papa Tongarewa, February 29, 2008.

Gibson, Stephanie. “Acquisition Proposal 3848 - Mac Plus computer guide.” Museum of New Zealand Te Papa Tongarewa, December 21, 2011.

Museum of New Zealand Te Papa Tongarewa Annual Report 2015/16

Museum of New Zealand Te Papa Tongarewa. 2016. Collections Online. URL: http://collections.tepapa.govt.nz, accessed October 4, 2016.

Policy on Collection Development at Te Papa 2007

Ross, Kirstie. "Acquisition Proposal 3528 - Philips black and white television set." Museum of New Zealand Te Papa Tongarewa, January 6, 2011.

Te Papa Collection Strategy 2016-2021, draft for discussion.

\section{Acts of Parliament}

Museum of New Zealand Te Papa Tongarewa Act.

\section{Reports}

Morris Hargreaves McIntyre, 'What it is to be Kiwi' A summative evaluation of Slice of Heaven: $20^{\text {th }}$ Century Aotearoa, September 2011.

Ross, Kirstie. “Collecting everyday material culture: Analysing KE EMu, Te Papa's Collection database." February 2, 2017. Text file.

\section{Unpublished theses}

Loud, Rebecca. "Never let me go? A case study of deaccessioning and disposal undertaken at Museum of Wellington City and Sea." Master's thesis, Victoria University of Wellington, 2013.

Schubert-McArthur, Tanja. ""Walking the Talk"? An Ethnography of Biculturalism at Te Papa." PhD thesis, Victoria University of Wellington, 2014.

Searle, Chloe. "Collecting for New Zealand: Examining What the Museum of New Zealand Te Papa Tongarewa Should Collect." Master's thesis, Victoria University of Wellington, 2010. 
Smith, Daniel, "City revealed: The process and politics of exhibition development." Master's Thesis, Massey University, 2003.

Speer, Frances. "Good use: a study of collection utilization at the Dunedin Public Art Gallery." Master's thesis, Victoria University of Wellington, 2006.

Townsend, Lynette. "Seen But Not Heard? Collecting the History of New Zealand Childhood." Master's thesis, Victoria University of Wellington, 2008.

Wagstaff, Blyss. "Jewellery as art and/or craft: an investigation of contemporary jewellery collections and collecting in New Zealand museum." Master's thesis, Victoria University of Wellington, 2008.

Williams, Matariki. "Ka hao te rangatahi: How is contemporary Māori society collected at Te Papa Tongarewa?” Master's thesis, Victoria University of Wellington, 2014.

\section{Websites}

“About Mō mātou - Museum of New Zealand Te Papa Tongarewa." Accessed February 6, 2017. https://www.tepapa.govt.nz/about

Geenty, Mark, Kevin Norquay and Laura Dooney. "“Amazed' Peter Snell still not yet convinced Olympic auction singlet is a fake.” Stuff.co.nz. June 30, 2016, sec. Sport. http://www.stuff.co.nz/sport/olympics/81613775/te-papa-cancels-purchase-of-petersnell-olympics-singlet

Museum of New Zealand Te Papa Tongarewa. "Object: Bag.” Accessed October 4, 2016. http://collections.tepapa.govt.nz/Object/53665

Museum of New Zealand Te Papa Tongarewa. "Object: Ball of thread." Accessed October 4, 2016. http://collections.tepapa.govt.nz/Object/1096190 


\section{Appendix I}

Interview questions

1. In terms of museum work, can you please tell me about your background and describe your current role?

[Prompt: when did you begin working in museums? What previous roles have you worked in?]

2. Where do acquisition and collection policies come from? How big of a role do you think they play?

[Prompt: Do you have input into it? What type?]

3. Has Te Papa's acquisition policy changed while you have worked here? How?

4. How do you source items you acquire?

[Prompt: Auctions? Online? Donations? Local/national/overseas?]

5. What are you looking for when you collect?

[Prompt: What do you think drives collecting? DO you have a set criteria? Do you consider what other museums are collecting? What about private collections?]

6. Once you have identified an item you want to collect, can you talk me through the acquisition process?

7. How would you define "everyday material culture"?

8. Do you collect everyday material culture yourself? [Prompt: and why?]

9. In terms of everyday material culture, what, in your opinion, is the current state of Te Papa's collection?

[Prompt: Is there much, or enough of it? Is it neglected, or a strong collection?]

10. In terms of the prioritisation of acquiring items for Te Papa's collections, where do you think social history falls?

[Prompt: perhaps compared to the art collection, or Maori/Pacific]

11. Is there a push to collect the extraordinary over the ordinary?

[Prompt: Do you find it hard to justify the acquisition of objects which bare no special quality?]

12. Do you see benefits in collecting everyday material culture?

13. What are some issues you see with collecting everyday material culture?

14. How do you see the future of collecting at Te Papa, and more specifically, the future of history collecting at Te Papa? 
[Prompt: what is your vision for Te Papa's collections?]

15. If you were starting from nothing, what would you collect?

[Prompt: where would you start? What would you priortise? If you were able, would you choose to collect everything?]

16. Do you believe there are things Te Papa should not be collecting?

[Prompt: Do you believe collections are central to what museums do? Damaged items? Items that lack provenance?]

17. Is there anything you think I have missed? Any last points you would like to make? 